\title{
Towards long-term standardised carbon and greenhouse gas observations for monitoring Europe's terrestrial ecosystems: a review
}

Daniela Franz ${ }^{1 *}$, Manuel Acosta ${ }^{2}$, Núria Altimir ${ }^{3,4}$, Nicola Arriga ${ }^{5}$, Dominique Arrouays ${ }^{6}$, Marc Aubinet $^{7}$, Mika Aurela $^{8}$, Edward Ayres ${ }^{9}$, Ana López-Ballesteros ${ }^{10}$, Mireille Barbaste ${ }^{11}$, Daniel Berveiller ${ }^{12}$, Sébastien Biraud ${ }^{13}$, Hakima Boukir ${ }^{6}$, Timothy Brown ${ }^{14}$, Christian Brümmer ${ }^{1}$, Nina Buchmann ${ }^{15}$, George Burba ${ }^{16,17}$, Arnaud Carrara ${ }^{18}$, Allessandro Cescatti ${ }^{19}$, Eric Ceschia ${ }^{20}$, Robert Clement ${ }^{21}$, Edoardo Cremonese $^{22}$, Patrick Crill ${ }^{23}$, Eva Darenova ${ }^{2}$, Sigrid Dengel ${ }^{13}$, Petra D'Odorico $^{15}$, Gianluca Filippa $^{22}$, Stefan Fleck ${ }^{24}$, Gerardo Fratini ${ }^{16}$, Roland Fu $\beta^{1}$, Bert Gielen ${ }^{5}$, Sébastien Gogo ${ }^{25,26,27}$, John Grace ${ }^{21}$, Alexander Graf ${ }^{28}$, Achim Grelle ${ }^{29}$, Patrick Gross ${ }^{30}$, Thomas Grünwald ${ }^{31}$, Sami Haapanala ${ }^{3,32}$, Markus Hehn ${ }^{31}$, Bernard Heinesch ${ }^{7}$,

Jouni Heiskanen ${ }^{33}$, Mathias Herbst ${ }^{34}$, Christine Herschlein ${ }^{35}$, Lukas Hörtnagl ${ }^{15}$, Koen Hufkens ${ }^{36}$, Andreas Ibrom ${ }^{37}$, Claudy Jolivet ${ }^{6}$, Lilian Joly ${ }^{38}$, Michael Jones ${ }^{10}$, Ralf Kiese ${ }^{35}$, Leif Klemedtsson ${ }^{39}$, Natascha Kljun ${ }^{40}$, Katja Klumpp ${ }^{41}$,

Pasi Kolari ${ }^{3}$, Olaf Kolle ${ }^{42}$, Andrew Kowalski ${ }^{43,44}$, Werner Kutsch ${ }^{33}$, Tuomas Laurila ${ }^{8}$, Anne de Ligne ${ }^{7}$, Sune Linder ${ }^{45}$, Anders Lindroth ${ }^{46}$, Annalea Lohila ${ }^{8}$, Bernhard Longdoz ${ }^{7}$, Ivan Mammarella ${ }^{3}$, Tanguy Manise ${ }^{47}$, Sara Marañón Jiménez ${ }^{43,48}$, Giorgio Matteucci ${ }^{49}$, Matthias Mauder ${ }^{35}$, Philip Meier ${ }^{15}$, Lutz Merbold ${ }^{15,50}$, Simone Mereu ${ }^{51}$, Stefan Metzger ${ }^{9,52}$, Mirco Migliavacca ${ }^{53}$, Meelis Mölder ${ }^{46}$, Leonardo Montagnani ${ }^{5,55}$, Christine Moureaux ${ }^{7}$, David Nelson $^{56}$, Eiko Nemitz ${ }^{57}$, Giacomo Nicolini ${ }^{51}$,

Mats B. Nilsson ${ }^{58}$, Maarten Op de Beeck ${ }^{5}$,Bruce Osborne ${ }^{59}$, Mikaell Ottosson Löfvenius ${ }^{58}$, Marian Pavelka ${ }^{2}$, Matthias Peichl ${ }^{58}$, Olli Peltola ${ }^{3}$, Mari Pihlatie ${ }^{3}$,Andrea Pitacco ${ }^{60}$, Radek Pokorný ${ }^{2}$, Jukka Pumpanen ${ }^{61}$, Céline Ratié, Corinna Rebmann ${ }^{62}$, Marilyn Roland ${ }^{5}$, Simone Sabbatini ${ }^{63}$, Nicolas P.A. Saby ${ }^{6}$, Matthew Saunders ${ }^{10}$, Hans Peter Schmid ${ }^{35}$, Marion Schrumpf ${ }^{53}$, Pavel Sedlák ${ }^{2,64}$, Penelope Serrano Ortiz ${ }^{44,65}$, Lukas Siebicke ${ }^{66}$, Ladislav Šigut ${ }^{2}$, Hanna Silvennoinen ${ }^{67}$,

Guillaume Simioni $^{68}$, Ute Skiba ${ }^{57}$, Oliver Sonnentag ${ }^{69}$, Kamel Soudani ${ }^{12}$, Patrice Soule ${ }^{11}$, Rainer Steinbrecher ${ }^{35}$,

Tiphaine Tallec $^{20}$, Anne Thimonier ${ }^{70}$, Eeva-Stiina Tuittila ${ }^{71}$, Juha-Pekka Tuovinen ${ }^{8}$, Patrik Vestin ${ }^{46}$, Gaëlle Vincent ${ }^{12}$, Caroline Vincke ${ }^{72}$, Domenico Vitale ${ }^{63}$, Peter Waldner ${ }^{70}$, Per Weslien ${ }^{39}$, Lisa Wingate ${ }^{36}$, Georg Wohlfahrt ${ }^{73}$,

$$
\text { Mark Zahniser }{ }^{56} \text {, and Timo Vesala }{ }^{3,74}
$$

${ }^{1}$ Thünen Institute of Climate-Smart Agriculture, Bundesallee 65, 38116, Braunschweig, Germany

${ }^{2}$ Department of Matter and Energy Fluxes, Global Change Research Institute, Czech Academy of Sciences, Bělidla 986/4a, 60300, Brno, Czech Republic

${ }^{3}$ Institute for Atmosphere and Earth System Research/ Physics, PO Box 68, Faculty of Science, University of Helsinki, Finland

${ }^{4}$ Forest Sciences Centre of Catalonia, Carretera de St. Llorenç de Morunys km 2, 25280, Solsona, Spain

${ }^{5}$ Research Centre of Excellence Plants and Ecosystems (PLECO), University of Antwerp, Wilrijk, Belgium

${ }^{6}$ INRA, US 1106 InfoSol, F-45000 Orléans, France

${ }^{7}$ TERRA Teaching and Research Centre, Gembloux Agro-Bio Tech, University of Liege, B-5030 Gembloux, Belgium

${ }^{8}$ Finnish Meteorological Institute, P.O. Box 503, 00101, Helsinki, Finland

${ }^{9}$ National Ecological Observatory Network, Batelle, 1685 38th Street, Boulder, CO 80301, United States

${ }^{10}$ School of Natural Sciences, Trinity College Dublin, College Green, D2, Dublin, Ireland

${ }^{11}$ US 1118 USRAVE, French National Institute for Agricultural Research (INRA), 71 ave E. Bourlaux CS20032, 33882 Villenave d'Ornon, France

${ }^{12}$ Ecologie Systématique Evolution, Univ. Paris-Sud, CNRS, AgroParisTech, Université Paris-Saclay, 91400 Orsay, France

${ }^{13}$ Climate Sciences Department, Lawrence Berkeley National Laboratory, 1 Cyclotron Road, B84-153, Berkeley, CA 94720, USA

${ }^{14}$ Australian Plant Phenomics Facility, ANU Node, Research School of Biology, Plant Science, Australian National University, Acton ACT 2601, Australia

${ }^{15}$ Institute of Agricultural Sciences, ETH Zurich, Universitätstrasse 2, 8092, Zurich, Switzerland

${ }^{16}$ Research and Development, LI-COR Biosciences, Lincoln, NE 68504, USA 
${ }^{17}$ Robert B. Daugherty Water for Food Institute and School of Natural Resources, University of Nebraska-Lincoln, NE 68583, USA

${ }^{18}$ Centro de Estudios Ambientales del Mediterráneo (CEAM), Parque Tecnológico C/ Charles R. Darwin 14, 46980, Paterna, Spain

${ }^{19}$ European Commission, Joint Research Center, Institute for Environment and Sustainability, Ispra, I-21027, Italy

${ }^{20}$ Centre d'Etudes Spatiales de la BIOsphère (CESBIO), Université Toulouse III, 18 avenue Edouard Belin bpi 2801, 31401,

Toulouse 9, France

${ }^{21}$ School of Geosciences, the University of Edinburgh, West Mains Road, EH9 3FF, Edinburgh, UK

${ }^{22}$ Environmental Protection Agency of Aosta Valley, Climate Change Unit, Loc. Grande Charriere, 44, 11020, St. Christophe, Italy

${ }^{23}$ Department of Geological Sciences, Stockholm University, Svante Arrhenius väg 8, 10691, Stockholm, Sweden

${ }^{24}$ Thünen Institute of Forest Ecosystems, Alfred-Möller-Str. 1, Haus 41/42, 16225 Eberswalde, Germany

${ }^{25}$ University of d'Orléans, ISTO, UMR 7327, 45071, Orléans, France

${ }^{26} \mathrm{CNRS}$, ISTO, UMR 7327, 45071 Orléans, France

${ }^{27}$ BRGM, ISTO, UMR 7327, BP 36009, 45060 Orléans, France;

${ }^{28}$ Institute of Bio- and Geosciences, Agrosphere (IBG-3), Forschungszentrum Jülich, Wilhelm-Johnen-Straße, 52428, Jülich, Germany

${ }^{29}$ Department of Ecology, Swedish University of Agricultural Sciences, 75007 Uppsala, Sweden

${ }^{30}$ UMR EEF, French National Institute for Agricultural Research (INRA), 54280 Champenoux, France

${ }^{31}$ Institute of Hydrology and Meteorology, Technische Universität Dresden, Pienner Straße 23, 01737 Tharandt, Germany

${ }^{32}$ Suvilumi - Environmental Measurements and Engineering, Pähkinätie 7 E, 00780 Helsinki

${ }^{33}$ ICOS ERIC Head Office, Erik Palménin aukio 1, 00560, Helsinki, Finland

${ }^{34}$ Zentrum für Agrarmeteorologische Forschung Braunschweig (ZAMF), Deutscher Wetterdienst, Bundesallee 33, 38116, Braunschweig, Germany

${ }^{35}$ Institute of Meteorology and Climate Research - Atmospheric Environmental Research (IMK-IFU), Karlsruhe Institute of

Technology (KIT), Kreuzeckbahnstraße 19, 82467, Garmisch-Partenkirchen, Germany

${ }^{36}$ INRA UMR 1391 ISPA, F-33140, Villenave-d'Ornon, France

${ }^{37}$ Department of Environmental Engineering, Technical University of Denmark, Bygningstorvet, 2800 Kgs. Lyngby, Denmark

${ }^{38}$ Groupe de Spectrométrie Moléculaire et Atmosphérique GSMA, Université de Reims-Champagne Ardenne, UMR CNRS 7331, Moulin de la Housse, BP 1039, 51687, Reims 2, France;

${ }^{39}$ Department of Earth Sciences, University of Gothenburg, Guldhedsgatan 5a, 40530 Göteborg, Sweden

${ }^{40}$ Centre for Environmental and Climate Research, Lund University, Sölvegatan 37, 22362 Lund, Sweden

${ }^{41}$ UR 874, UREP, Grassland Ecosystem Research Team, French National Institute for Agricultural Research (INRA), 63100, Clermont-Ferrand, France

${ }^{42}$ Max Planck Institute for Biogeochemistry, P.O. Box 1001 64, 07701, Jena, Germany

${ }^{43}$ Department of Applied Physics, University of Granada, Granada, Spain

${ }^{44}$ Andalusian Institute for Earth System Research (CEAMA-IISTA), Universidad de Granada, 18006, Granada, Spain

${ }^{45}$ Swedish University of Agricultural Sciences (SLU), Southern Sweden Forest Research Center, 23053, Alnarp, Sweden

${ }^{46}$ Department of Physical Geography and Ecosystem Science, Lund University, Sölvegatan 12, 223 62, Lund, Sweden

${ }^{47}$ AGROBIOCHEM Research Unit, Gembloux Agro-Bio Tech, University of Liege, B-5030 Gembloux, Belgium

${ }^{48}$ Centre for Research on Ecology and Forestry Applications (CREAF), Cerdanyola del Vallès, 08193 Barcelona, Spain

${ }^{49}$ Institute for Agriculture and Forestry Systems in the Mediterranean ISAFoM, Italian National Research Council, Via Patacca 85 Ercolano, Italy

${ }^{50}$ Mazingira Centre, International Livestock Research Institute (ILRI), P.O. Box 30709, 00100, Nairobi, Kenya

${ }^{51}$ Euro-Mediterranean Center on Climate Change, Impacts on Agriculture, Forests and Natural Ecosystems (IAFES) Division, via De Nicola 9, 07100, Sassari, Italy

${ }^{52}$ University of Wisconsin-Madison, Dept. of Atmospheric and Oceanic Sciences, 1225 West Dayton Street, Madison, WI 53706, USA

${ }^{53}$ Department Biogeochemical Integration, Max Planck Institute for Biogeochemistry, P.O. Box 100164, 07701, Jena, Germany

${ }^{54}$ Faculty of Science and Technology, Free University of Bolzano, Piazza Universita' 1, 39100, Bolzano, Italy

${ }^{55}$ Forest Services, Autonomous Province of Bolzano, Via Brennero 6, 39100, Bolzano, Italy

${ }^{56}$ Aerodyne Research, Inc., 45 Manning Road, Billerica, MA, 01821-3976, USA

${ }^{57}$ Centre for Ecology and Hydrology, Edinburgh, Bush Estate, Penicuik, Midlothian, EH26 0QB, UK

${ }^{58}$ Department of Forest Ecology and Management, Swedish University of Agricultural Sciences, SE-90183, Umeå, Sweden

${ }^{59}$ UCD School of Biology \& Environmental Science, and UCD Earth Institute, University College Dublin, Belfield, Dublin 4, Ireland

${ }^{60}$ Department of Agronomy, Food, Natural Resources, Animals and Environment - DAFNAE, University of Padova, Legnaro, Italy

${ }^{61}$ Department of Environmental and Biological Sciences, University of Eastern Finland, Yliopistonranta 1 C, 70211, Kuopio, Finland

${ }^{62}$ Department Computational Hydrosystems, Helmholtz Centre for Environmental Research - UFZ, Permoserstraße 15, 04318, Leipzig, Germany;

${ }^{63}$ Department for Innovation in Biological, Agro-food and Forest Systems (DIBAF), University of Tuscia, Via S Camillo de Lellis snc, 01100, Viterbo, Italy

${ }^{64}$ Institute of Atmospheric Physics, CAS, Bocni II, 1401, 14131 Prague 4, Czech Republic

${ }^{65}$ Department of Ecology, University of Granada, 18071, Granada, Spain

${ }^{66}$ University of Goettingen, Bioclimatology, Büsgenweg 2, 37077, Göttingen, Germany 


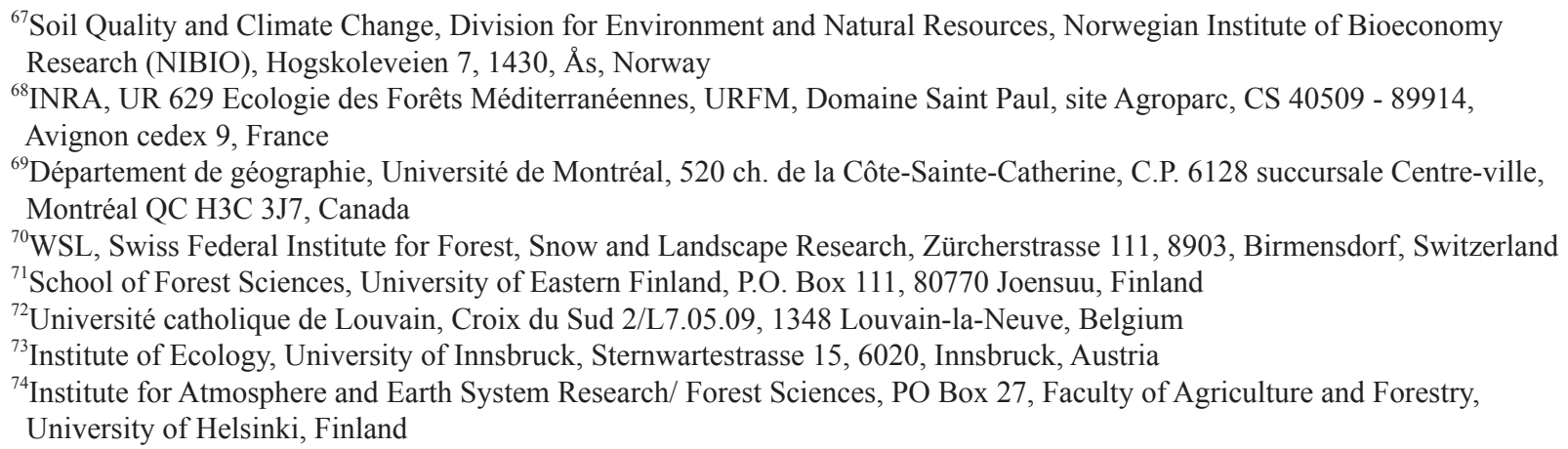

Received January 16, 2018; accepted July 11, 2018

\begin{abstract}
Research infrastructures play a key role in launching a new generation of integrated long-term, geographically distributed observation programmes designed to monitor climate change, better understand its impacts on global ecosystems, and evaluate possible mitigation and adaptation strategies. The pan-European Integrated Carbon Observation System combines carbon and greenhouse gas ( $\left.\mathrm{GHG} ; \mathrm{CO}_{2}, \mathrm{CH}_{4}, \mathrm{~N}_{2} \mathrm{O}, \mathrm{H}_{2} \mathrm{O}\right)$ observations within the atmosphere, terrestrial ecosystems and oceans. High-precision measurements are obtained using standardised methodologies, are centrally processed and openly available in a traceable and verifiable fashion in combination with detailed metadata. The Integrated Carbon Observation System ecosystem station network aims to sample climate and land-cover variability across Europe. In addition to GHG flux measurements, a large set of complementary data (including management practices, vegetation and soil characteristics) is collected to support the interpretation, spatial upscaling and modelling of observed ecosystem carbon and GHG dynamics. The applied sampling design was developed and formulated in protocols by the scientific community, representing a trade-off between an ideal dataset and practical feasibility. The use of open-access, high-quality and multi-level data products by different user communities is crucial for the Integrated Carbon Observation System in order to achieve its scientific potential and societal value.

Keywords: ICOS, GHG exchange, carbon cycle, standardised monitoring, observational network
\end{abstract}

\section{INTRODUCTION}

Anthropogenic climate change is one of the greatest global challenges that our society faces in the 21 st century and beyond. The major driving force of recent and future anthropogenic climate change is the human perturbation of biogeochemical and energy cycles, including the welldocumented escalation of atmospheric greenhouse gas (GHG) concentrations, especially carbon dioxide $\left(\mathrm{CO}_{2}\right)$, methane $\left(\mathrm{CH}_{4}\right)$ and nitrous oxide $\left(\mathrm{N}_{2} \mathrm{O}\right)$ since pre-industrial times (IPCC, 2013, Kirschke et al., 2013; Jackson et al., 2016). In view of the expected threats associated with climate change, the development of mitigation and adaptation strategies are among the top priorities of international governance. The Paris Agreement, which builds upon the
United Nations Framework Convention on Climate Change (UNFCCC), entered into force in 2016 with the aim of limiting 21 st-century global mean air temperatures to a maximum of $2^{\circ} \mathrm{C}$ above pre-industrial levels (Rogelj et al., 2016). A prerequisite for successful climate change mitigation and adaptation efforts is knowledge of the key drivers, characteristics and impacts of climate change on ecosystem processes, which can only be obtained through geographically extensive, robust, consistent and reliable long-term observations (Seneviratne et al., 2018). In-situ measurements, integrating the Earth system domains (1) atmosphere, (2) terrestrial and freshwater ecosystems (hereafter referred to as 'terrestrial ecosystems' only) and (3) ocean through continental-scale research infrastructures (RIs) with broad geographical representativeness, are most appropriate for these purposes (Ciais et al., 2014; Papale et al., 2015; Kumar et al., 2016). The Integrated Carbon Observation System (ICOS) is a pan-European RI that provides high-precision observations in a standardised, traceable and verifiable manner for the three Earth system domains. The focus of these challenging efforts is on the carbon (C) cycle and GHGs $\left(\mathrm{CO}_{2}, \mathrm{CH}_{4}, \mathrm{~N}_{2} \mathrm{O}, \mathrm{H}_{2} \mathrm{O}\right)$. Observations of energy, water and nitrogen $(\mathrm{N})$ cycle components are only partly included in the ICOS portfolio and not addressed in detail in this paper.

\section{Benefits of long-term, integrated in-situ observations as provided by ICOS}

The atmosphere, terrestrial ecosystems and oceans are closely interconnected through energy and matter exchange (such as latent heat and the cycling of $\mathrm{C}$ and N). Respective sources and sinks interact with each other and the rates at which the elements are sequestered or released vary in response to changing biotic and abiotic conditions. For $\mathrm{CO}_{2}$, Ballantyne et al. (2012) provided a mass balance analysis based on global atmospheric $\mathrm{CO}_{2}$ concentration measurements and emission inventories. They estimated that global uptake of anthropogenically emitted $\mathrm{CO}_{2}$ by terrestrial ecosystems and oceans doubled from $1960\left(2.4 \pm 0.8 \mathrm{Pg} \mathrm{C} \mathrm{a}^{-1}\right)$ 
to $2010\left(5.0 \pm 0.9 \mathrm{Pg} \mathrm{C} \mathrm{a}^{-1}\right)$ in response to increased atmospheric $\mathrm{CO}_{2}$. Ballantyne et al. (2012) stated that the total uptake during these 50 years corresponds to $55 \%$ of the anthropogenic $\mathrm{CO}_{2}$ emitted during the same period. However, there are ongoing discussions about the magnitudes of effects on the atmospheric $\mathrm{CO}_{2}$ budget by terrestrial ecosystems and oceans individually, the location and status of the dominant large-scale $\mathrm{CO}_{2}$ sinks, and the future evolution of sinks and sources (Ciais et al., 1995; Canadell et al., 2007; Pan et al., 2011; Levin, 2012; Wanninkhof et al., 2013). The estimates from the Global Carbon Project (GCP) for the global terrestrial and oceanic $\mathrm{C}$ uptake in 2017 were of $2.7 \pm 1.0 \mathrm{Pg} \mathrm{C} \mathrm{a}^{-1}$ and 2.6 40.5 $\mathrm{Pg} \mathrm{C} \mathrm{a}{ }^{-1}$, respectively, which together offset $47 \%$ of current annual anthropogenic $\mathrm{CO}_{2}$ emissions (Le Quéré et al., 2018). In general, such estimates and scenarios for the global $\mathrm{C}$ cycle improve with measurement precision and refined modelling of the global biogeochemical cycles, but still involve considerable uncertainties (Peters, 2018). Discrepancies between the $\mathrm{C}$ cycle components raise the question of whether we are still missing essential reservoirs and processes that influence the budgets and if our current observational strategies are appropriate to resolve them (Ballantyne et al., 2012; Levin, 2012; Le Quéré et al., 2016). Monitoring approaches need to integrate observations of the atmosphere, terrestrial ecosystems and oceans to allow detection of potentially missing sources, sinks and driving processes. It is clear that a lack of long-term routine sampling, with standardisation and sufficient temporal and spatial coverage, continues to limit understanding and quantification of global biogeochemical cycles including natural and anthropogenic GHG emissions (Le Quéré et al., 2016).

The time scale of climate-related changes and the turnover times of the major $\mathrm{C}$ pools range from months to millennia. Long-term atmospheric, biogeochemical and ecological datasets are crucial to better understand the spatio-temporal scales of environmental variability, to attribute changes to a particular forcing process and to identify temporally shifted or gradually changing ecological responses (Bonan et al., 2012; Baldocchi et al., 2012). Long-term observations reveal susceptibilities and critical shifts in ecosystem functioning and services, and identify ecosystem responses to short-term anomalies and extreme events (Reichstein et al., 2007; Chu et al., 2017). With strong environmental changes expected in the next few decades, such long-term datasets should cover a relevant timeframe ( $\geq 20$ years).

Continuous monitoring of GHG concentrations and fluxes is also crucial for GHG projections and to foresee climate-related scenarios such as Representative Concentration Pathways (RCPs; van Vuuren et al., 2011). Longterm observations with a high level of standardisation further build the capacity for cross-site synthesis activities. Long-term observations can help to reveal spatial GHG flux patterns and produce continental- and global-scale flux maps by combining network flux data, remote sensing and coupled ecosystem-climate models (Baldocchi, 2014). They can further support compulsory GHG emission inventories and independent GHG emissions verification, and help define and evaluate climate change mitigation and adaptation strategies such as climate-smart land-use management practices (Ceschia et al., 2010; Bellassen and Luyssaert, 2014).

Modelling capabilities are rapidly growing with our understanding of the Earth system and sophisticated data assimilation techniques, and are improving the quality of climatic and ecological predictions (Millar et al., 2017; Goodwin et al., 2018; Niu et al., 2014). This increases the demand for in-situ observations for model development, in order to better constrain parameterisations, to independently evaluate model performance, and to reduce uncertainties in model predictions (Bonan et al., 2012; Schmid, 2012). Such demand is particularly significant for bottom-up model approaches that estimate C and GHG budgets at local, regional and global scales (e.g. Jung et al., 2009, 2011; Osborne et al., 2010; Schulze et al., 2010; Smith et al., 2010; Zhu et al., 2014; Kondo et al., 2015; Zscheischler et al., 2017), and for Earth System Models (ESMs), that include biogeochemical components and biosphere-atmosphere flux algorithms (Williams et al., 2009; Bonan et al., 2012; Baldocchi et al., 2012). Furthermore, in-situ observations provide a priori knowledge for inverse modelling and can validate top-down modelling approaches based on atmospheric GHG concentration measurements (Wanninkhof et al., 2013; Houweling et al., 2017; Leip et al., 2018). Inverse modelling approaches are extremely useful in determining a regional GHG budget, but depend strongly on a dense observational network (Villani et al., 2010; Kadygrov et al., 2015). Additionally, in-situ observations are needed to validate airborne and satellite remote sensing products (such as gross primary production, pigment indices, vegetation indices and related products), which are increasingly applied to quantify the changes in global $\mathrm{C}$ and $\mathrm{N}$ budgets.

Evolution of European GHG observations from projectbased networks to a research infrastructure

The International Biological Program (IBP, 1964-1974) was among the first implemented Big Science projects in biology. It provided insights into ecosystem responses to climate change, e.g. the GHG exchange between ecosystems and the atmosphere, and inspired subsequent long-term ecological and environmental observation networks such as LTER (Long Term Ecological Research). However, already during the 1950s attempts were made to develop $\mathrm{CO}_{2}$ observation and data assimilation programmes (Fonselius, 1958). An active and persistent scientific community developed many international GHG concentration and flux measurement networks and programmes for 
terrestrial ecosystems, atmosphere and oceans. These arose in Europe and elsewhere over recent decades (Fig. 1, Table A3), with strong support from the European Commission and national funding sources. Particularly the early network approaches were geographically limited and only covered one or two of the three domains. In the case of terrestrial ecosystems, GHG networks often focussed more on certain ecosystem types and on specific rather than comprehensive coverage of key processes and components of the $\mathrm{C}$ cycle and biosphere-atmosphere GHG exchange. The eddy covariance (EC) technique was initially applied for campaigns of a few months only instead of long-term monitoring. It involves the use of expensive precision devices, which further limited the spatial coverage of these direct flux measurements. Furthermore, in earlier programmes and networks metadata and observations supporting the analysis and interpretation of the measurements were often neglected or not published, hampering in-depth process understanding and the reproducibility of the results. Varying measurement techniques and data processing procedures resulted in limited comparability, and consequently increased the uncertainty in analysis outcomes and model predictions. Data precision conventions were also mostly absent, adding to modelling uncertainties which depend both on model structure (representing our understanding of the processes) and on the quality of parameterisation data. Furthermore, data were often stored in different formats and archived separately for each project/network, limiting the potential benefits of data sharing and integra- tive model assimilation. However, the scientific outcome of these early network initiatives was often of the highest quality and reflected the state-of-the-art methodology available at the time. While frequent scientific reorientation and short project durations limited the confident extrapolation of short-term datasets to long-term trends, these early initiatives still raised important questions about our understanding of $\mathrm{C}$ and GHG dynamics within and across ecosystems. The urgent need for a thorough, consistent and long-term data collection and analysis approach integrating the three Earth system domains, initiated the transition from a short-term, project-based framework to ICOS as a highly integrated RI over the last 15 years.

\section{ICOS within the European and global observation and research landscape}

Two milestones significantly influenced the development of ICOS as a European RI. The first was the formulation of global observational necessities by the Subsidiary Body for Scientific and Technical Advice (SBSTA) of the United Nations Framework Convention on Climate Change (UNFCCC). ICOS is thereby based on a sub-system of the 'Essential Climate Variables' (ECVs; physical, chemical or biological variables or groups of linked variables that critically contribute to the characterisation of the Earth's climate) called 'Essential Carbon Cycle Variables'. Deeply rooted in this (sub-)system - documented in the Implementation Plan of the Global Climate Observation System (GCOS) - ICOS aims to evolve into the European pillar of a future global

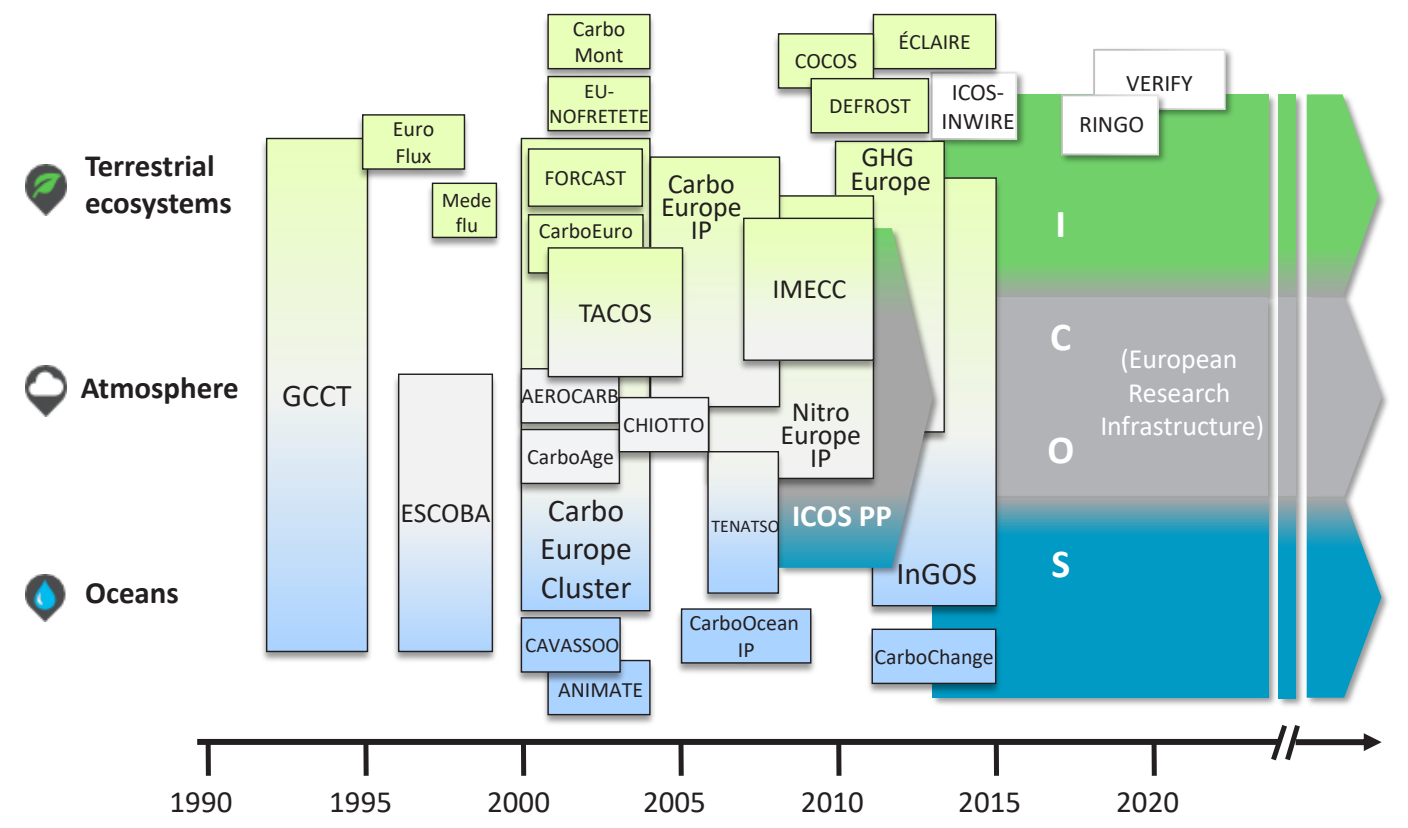

Fig. 1. The evolution of (selected) European project-based C, N and GHG observation networks and programmes for the three Earth system domains towards ICOS as integrated RI. Acronyms are explained in Tables A2 and A3. The white boxes on the right indicate recent ICOS projects. 
GHG observation system. With this future growth in mind, ICOS is developing a comprehensive cross-domain array of atmosphere, terrestrial ecosystem and ocean observations, as required for an in-depth understanding and conceptualisation of biogeochemical cycles evolving under a changing climate. This approach will enable ICOS to significantly contribute to a number of scientific network programmes such as the World Meteorological Organisation (WMO)driven Integrated Global Greenhouse Gases Information System ( $\mathrm{IG}^{3} \mathrm{IS}$ ), the Group on Earth Observation (GEO) Carbon and GHG Initiative (GEO-C), and the European Earth Observation Programme (COPERNICUS).

The second milestone for the transition to a European RI was the development of the European Strategic Forum for Research Infrastructures (ESFRI). ESFRI put ICOS on its first roadmap in 2006 and identified it as a 'Landmark' in 2016, transforming ICOS into an RI of pan-European interest corresponding to the long term needs of the European research communities. ICOS has an active role in the development of the European Environmental Research Infratructure (ENVRI) landscape as well. Consolidation of the ESFRI landscape is pursued via interoperability with other ENVRIs (e.g. IAGOS, ACTRIS, Lifewatch, AnaEE, eLTER RI; EuroArgo and EMSO; Table A3), yielding synergies from joint measurement strategies, common standards, and the co-location of sites or common data life cycles.

\section{The pan-European research infrastructure ICOS}

ICOS is a distributed European RI providing in-situ standardised, traceable and verifiable, high-precision observations of lower atmosphere GHG concentrations as well as biosphere-atmosphere GHG fluxes, where measurements are intended to last for $\geq 20$ years. The observations are complemented by a large set of multi-disciplinary data required to document changes in ecosystem composition, structure and functioning and for the interpretation and modelling of the observed GHG concentrations and fluxes (Table A1). The overarching goal of ICOS is to facilitate high-quality research on the status, future responses and driving forces of GHG and C cycle dynamics, as well as the role of atmospheric, terrestrial and oceanic systems in the development of, and response to, future climate change. ICOS aims to enhance our understanding of the GHG balance of the European continent and adjacent regions, in addition to evaluating GHG emission mitigation and adaptation strategies (Gielen et al., 2017). Its mission also includes education, capacity building and the promotion and implementation of technological advancements.

The RI provides a network of measurement stations classified based on their level of standardisation to obtain a comprehensive picture of $\mathrm{C}$ cycle and GHG dynamics and their spatial and temporal variability across Europe and adjacent regions. A major challenge is to provide cross-domain integration while maintaining high quality scientific outcomes in each domain (Gielen et al.,
2017). The implementation of ICOS has been based on the bottom-up development of measurement standards and protocols, which has been led by the scientific community. Furthermore, ICOS implements the attributes that were identified to be important for effective observation networks, including an integrated data management structure, facilitating effective data sharing and assimilation, and a scientific network engaged with frequent communication, dissemination and joint scientific development (Baldocchi et al., 2012).

ICOS follows the monitoring principles of the GCOS and the measurement recommendations from the Global Earth Observation System of Systems (GEOSS). Data collection, processing and archiving are harmonised and standardised. Furthermore, ICOS aims to ensure comparability with the set of ancillary measurements made within existing networks such as the International Co-operative Programme on Assessment and Monitoring of Air Pollution Effects on Forests (ICP Forests) to facilitate upscaling. However, some flexibility to adjust the measurements to local site conditions and to benefit from technological innovations during the life-time of the infrastructure is retained. New measurement techniques and instruments are consolidated and thoroughly tested before they can be applied at the stations.

An overview on the organisational structure of ICOS is presented in Gielen et al. (2017). The individual institutions contributing to the national networks provide data from the standardised stations that are processed and quality controlled by the Central Facilities. The centralised data processing, which is based on open-source scripts, yields comparable data products of adequate and known quality and includes an estimate of their uncertainty. Various levels of data products are archived for the long-term storage in the repository offered by the Carbon Portal (https://www. icos-cp.eu). The ICOS database represents a common, openaccess archive with a data set identifier system and clearly defined data usage policies (https://www.icos-ri.eu/sites/ default/files/cmis/ICOS\%20RI\%20Data\%20Policy.pdf). This ensures verifiable, reproducible and transparent science, and accelerates scientific progress while returning scientific impact for the data producers (Nosek et al., 2015; Dai et al., 2018).

\section{GHG OBSERVATIONS IN TERRESTRIAL ECOSYSTEMS}

The terrestrial biosphere plays a central role in regulating the climate through physical, chemical and biological processes (Bonan et al., 2012), and reacts to changes in climate with both positive and negative climate-ecosystem feedback mechanisms (Heimann and Reichstein, 2008; Arneth et al., 2010; Frank et al., 2015). In order to better understand the links between terrestrial ecosystems and both the regional and global climate systems, improved knowledge of terrestrial $\mathrm{C}$ pathways and GHG exchange 
processes are required. However, the terrestrial $\mathrm{C}$ cycle represents the component of the global $\mathrm{C}$ budget with the highest observed variability and greatest measurement uncertainties (Bousquet et al., 2000; Bloom et al., 2016; Le Quéré et al., 2016). A growing observational network and associated database will therefore continuously improve our understanding of the interactions between terrestrial ecosystems and the climate system (Valentini et al., 2000; Baldocchi, 2008). For example, recent findings have highlighted the relationship between climatic extremes and the associated climate feedbacks of the terrestrial $\mathrm{C}$ cycle (Ciais et al., 2005; Reichstein et al., 2007; 2013, Frank et al., 2015; Xiao et al., 2016).

Since the 1990s the routine use of EC technique for tower-based $\mathrm{C}$, water and heat flux measurements has provided continuous observations over multiple years at a variety of sites and biomes in different climatic zones. Such measurements were identified as critical tools for the quantification of global and regional GHG dynamics, especially when conducted in combination with remote sensing observations and ESMs (Baldocchi, 2014). The EC approach is an established and robust technique to quantify turbulent exchanges of scalars, such as trace gases, momentum and energy, between the Earth's surface and the atmosphere (Aubinet et al., 2000). Fluxes of the variables of interest are calculated through the covariance of the mean deviations in vertical wind velocity and the respective scalar of interest (Desjardins and Lemon, 1974; Aubinet et $a l ., 2000)$. These quasi-continuously measurement systems impose minimal disturbance on the environment once operational, and recent technological advances have resulted in a new generation of EC instrumentation characterised by low-power and maintenance demands, depending on the scalar of interest. The fundamental utility and application of EC GHG flux measurements includes an assessment of the ecosystem response to environmental perturbations across various sites. This then allows for the derivation of GHG budgets, inter-annual and inter-site comparisons as well as the spatial scaling of GHG exchange (Baldocchi, 2003, 2014; Baldocchi et al., 2017).

Since the early 2000s standardisation in GHG flux data acquisition, processing and provision has been improved with the development of FLUXNET (Baldocchi et al., 2001), a global network of regional flux tower networks, such as CarboEurope IP, AmeriFlux, Fluxnet-Canada, Asiaflux, CarboAfrica (Sub-Saharan Africa) and OzFlux (Australia and New Zealand, Table A3). The FLUXNET database has already provided important new insights into the course and consequences of environmental change (Baldocchi, 2005, 2008; Falge et al., 2002; Law et al., 2002; Schwalm et al., 2009, 2017; Richardson et al., 2010; Migliavacca et al., 2011; Keenan et al., 2013; Wolf et al., 2016) and will further benefit in the future from the inclusion of ICOS data facilitated by its open-access policy. In addition, the rapid development of new measurement tech- niques including infrared gas analysers and laser absorption spectrometers, and an increasing number of modelling approaches at various spatio-temporal scales have resulted in considerable progress in our understanding of the processes and impacts of environmental change, e.g., for the European continent (Ciais et al., 2005; Jung et al., 2007).

Long-term EC datasets ( $>20$ years) are currently available for particular forest sites such as the Harvard Forest (Massachusetts, US, since 1991; Urbanski et al., 2007), the Takayama Forest (Japan, since 1993; Saigusa et al., 2005), Howland Forest (Maine, US, since 1996; Hollinger et al., 2004), the Anchor Station Tharandt (Germany, since 1996; Grünwald and Bernhofer, 2007), Sorø Forest (Denmark, since 1996; Pilegaard et al., 2011), the SMEAR II field measurement station (Hyytiälä, Finland, since 1996; Ilvesniemi et al., 2009) and the mountain forest station in Davos (Switzerland, since 1997; Etzold et al., 2011). The latter four stations are ICOS Candidate stations (currently undergoing either step 1 or 2 in the station labelling process). For forest ecosystems, intensive long-term monitoring activities were established and harmonised in Europe in the 1980s, through the ICP Forests under the frame of United Nations Economic Commission for Europe (UNECE). However, this network does not include the quasi-continuous terrestrial biosphere-atmosphere GHG exchange measurements implemented by ICOS (UNECE ICP Forests Programme Co-ordinating Centre, 2016; Danielewska et al., 2013, Ferretti and Fischer, 2013).

First European cropland stations were established in the early 2000s and results were integrated by Ceschia et al. (2010), Osborne et al. (2010), Eugster et al. (2010) and Kutsch et al. (2010). Some of these early stations, namely Borgo Cioffi (Italy, since 2001; Vitale et al., 2016), Gebesee (Germany, since 2001; Anthoni et al., 2004), Klingenberg (Germany, since 2004; Prescher et al., 2010), Grignon (France, sine 2004; Loubet et al., 2011) and Lonzée (Belgium, since 2004; Aubinet et al., 2009) have been running continuously since then and will now be continued within ICOS.

Similarly, most European long-term grassland stations were established in the early 2000s, including Neustift (Austria, since 2001; Wohlfahrt et al., 2008), Laqueuille (France, since 2002; Soussana et al., 2007) Grillenburg (Germany, since 2002; Soussana et al., 2007) and Monte Bondone (Italy, since 2002; Marcolla et al., 2011), whereby the latter three are contributing to the ICOS ecosystem station network. Early results were integrated for Europe by Gilmanov et al. (2007) and Soussana et al. (2007) and globally by Gilmanov et al. (2010) and Soussana et al. (2010).

Long-term EC measurements over wetlands have been started in the late 1990s, e.g. at Kaamanen (Finland, since 1997; Aurela et al., 2004), Zackenberg (fen, Greenland, since 1996; Soegaard et al., 2000) and the Mer Bleue peatland (Canada, since 1998; Lafleur et al., 2003). Apart from Kaamanen and Zackenberg, ICOS ecosystem stations with 
long-term measurements of at least one decade include Degerö (Sweden, since 2001; Peichl et al., 2014), AbiskoStordalen Palsa Bog (Sweden, since 2001; Christensen et al., 2012), Siikaneva (Finland, since 2005; Rinne et al., 2007), Třeboň (Czech Republic, since 2006; Dušek et al., 2012) and Auchencorth Moss (UK, since 2002; Helfter et al., 2015).

\section{The ICOS ecosystem station network}

The ICOS network of terrestrial ecosystem stations aims to represent the variability in climate and land cover throughout Europe. It covers the four main terrestrial ecosystem types which are most relevant to access GHG exchange across the European continent (forests, croplands, grasslands and wetlands) and which have been commonly observed within historic GHG observation programmes (e.g. GHG Europe). The network further includes stations in more locally dominant ecosystem types: heath/ shrublands, short rotation forestry (SRF) plantations, freshwater lakes and urban environments. Lakes have been included within the ICOS ecosystem network due to their importance in the global C and GHG cycle (Cole et al., 1994, 2007; Battin et al., 2009; Tranvik et al., 2009). Holgerson and Raymond (2016) estimated a net $\mathrm{C}$ loss from non-running inland waters of $0.58 \mathrm{Pg} \mathrm{C} \mathrm{a}^{-1}$, which is about one-fifth of the global terrestrial C uptake (Le Quéré et al., 2018). The inclusion of urban environments into the ICOS ecosystem network is justified due to the role of these areas as a major source of anthropogenic GHGs, and the ongoing trend of urbanisation in Europe (The European Union, 2016) and across the globe (United Nations, 2014). Common GHG monitoring approaches in cities are typically based on emission inventories aggregated for different sectors (road transport, industry, etc.). In comparison, the EC method has the advantage of integrating the heterogeneous urban GHG sources and sinks with sufficient spatio-temporal resolution to distinguish the contributing processes and their drivers, despite methodological limitations (limited footprints and complex surfaces with specific roughness) (Velasco and Roth, 2010; Liu et al., 2012).

Sampling design at ecosystem stations: a balancing act between a comprehensive setup and practical feasibility

A major challenge during the design phase of any ecosystem observation network is the identification of the essential environmental variables to be measured, their temporal frequency and spatial representativeness. The answer represents a trade-off between an ideal dataset that enhances our current process understanding and addresses key knowledge gaps, and the practical feasibility of an ambitious measurement plan in terms of budget, human resources and the sustainability of long-term infrastructure deployment. The ICOS Ecosystem Monitoring Station Assembly (MSA) and the Ecosystem Thematic Centre (ETC) have devised a trade-off that is built on the expe- riences of previous monitoring and experimental research networks. These include the identification of key components for GHG observations in terrestrial ecosystems (variables and sampling design) combined with general recommendations on the structure of monitoring networks (Hari et al., 2009, 2016; Baldocchi et al., 2012; Paoletti et al., 2014; Kulmala, 2018) and the careful consideration of the requirements from multiple data user categories. The potential users of ICOS data include the scientific communities as well as national and international programmes and environmental agencies, information service providers (e.g. COPERNICUS projects), public and private entities as well as educational organisations (Kaukolehto and Vesala, 2014). Fisher et al. (2018) recently highlighted the need to integrate observations with stakeholder requirements at an early stage of network design, e.g. the data requirement for modelling activities and syntheses.

Similar to most of the recent national and international GHG monitoring initiatives (Baldocchi, 2014; Baldocchi et al., 2012), EC flux measurements are at the core of all ICOS ecosystem stations. However, the ecosystem station network goes far beyond an EC flux-tower network. It comprises an optimised system to measure the storage change of GHGs in the air column underneath the EC system in addition to chamber-based soil-atmosphere GHG flux measurements. A broad set of ancillary measurements (including soil and vegetation characteristics) are also implemented to observe site-specific abiotic and biotic conditions (Pilegaard et al., 2011) and to support the analysis, interpretation, scaling and modelling of GHG fluxes (Fernández-Martínez et al., 2017; Keenan et al., 2013; Wu et al., 2013).

The ICOS ecosystem stations are categorised according to the number of variables measured and replicated design, and are classified as Class 1, Class 2 and Associated Stations (Table A1). The various levels of station designs facilitate flexibility in the site setup requirements and will ensure greater participation by the scientific community. Class 1 Stations represent 'supersites' with the most extensive standardised measurement criteria including continuous high-frequency measurements of the key $\mathrm{C}$ cycle compounds such as $\mathrm{CO}_{2}$ and $\mathrm{CH}_{4}$ where relevant for the particular ecosystem (e.g. wetlands or lakes) or $\mathrm{N}$ compounds in agroecosystems. These stations are especially valuable for in-depth studies of biophysical processes and model parameterisations (Skiba et al., 2009). The spatial spread of measurements across Europe is provided by a dense network of Class 2 stations, where fewer variables and replications of these measurements are required. However, the same level of measurement accuracy is required for station Classes 1 and 2. The measurement setup at Associated stations has to follow a less rigid level of standardisation, however, these stations still undergo an evaluation in order 
to meet ICOS data quality conventions while increasing the spatial representativeness of the different ecosystem types within the network.

The standardised procedures for the key observations required at ICOS ecosystem stations are described in 13 measurement protocols published in this issue of International Agrophysics, while specific instruction documents provide a guide to their practical implementation (www.icos-etc.eu/documents/instructions). However, the ICOS methodology is expected to further develop over time by revised measurement requirements according to the practical experience of the network and by implementing new technological developments following extensive testing periods. The protocols and instructions facilitate harmonised and comparable high-quality measurements that are essential for contributing to the overall goals of ICOS. A two-stage labelling process by the ETC ensures that all ICOS ecosystem stations fulfil the specific requirements of the ICOS station classes. The labelling process is required for both newly established and existing ecosystem stations applying to join the ICOS ecosystem network. In the first stage the suitability of the proposed station is evaluated in terms of characteristics and contribution to the network (e.g. representativeness and number of similar stations already included in ICOS). Technical evaluation criteria such as EC footprint, including fetch homogeneity, canopy conditions as well as the physiographic setting, are important theoretical assumptions to be met for EC measurements. However, the station setup can still be optimised during the ongoing labelling process. In the second stage the protocols for the station class specific variables need to be correctly implemented at the station. The station PI can ask for exceptions to the protocols if the standard methodology cannot be applied, e.g. an optical precipitation measurement instrument is admissible as an exception where no appropriate open space can be found near forest sites for weighing gauge measurements (Dengel et al., 2018). These site specific exceptions are documented and publicly available for the data user community. Furthermore, at this second stage robust data collection and transfer to the ETC needs to be established for Class 1 and Class 2 Stations, whereas for Associated Stations the data (calculated by station team, half-hourly) has to be submitted once a year.

\section{Measurement overview}

Site characterisation

An essential aspect of ICOS datasets is a sufficiently detailed site characterisation (Saunders et al., 2018). This includes information on the general site conditions, a description of the site history and an initial soil and vegetation survey with information on the main wind directions. The site characterisation further includes regularly updated information on site management practices and related lateral fluxes, soil cultivation and site amendments, as well as abiotic and biotic disturbance events. It is documented and regularly updated for all dynamic variables at timescales relative to the collection of the information (e.g. for soil organic carbon stocks (SOCS) at least every ten years) to provide a coherent assessment of the site. The site characterisation is an especially important tool during the setup of new ICOS ecosystem stations, as it is necessary for selecting the target area, positioning the EC tower and sampling plots for soil and vegetation measurements. Along with detailed metadata records (station PI contact details, observed variables, instruments installed, their location, specifications, calibrations etc.) the tracking, documentation and sharing of site characteristics is also important to gain transparency and traceability of the measurement setup and observations and to facilitate a comprehensive understanding of the site conditions for the data end user.

\section{Continuous measurements and repeated surveys}

The variables required for continuous measurement and repeated surveys at ICOS Class 1 and Class 2 ecosystem stations are summarised in Table A1 for the different ecosystem types. This list excludes the ecosystem types heath/ shrubland, SRF, urban environment and lake, as the respective required variables are still under discussion (June 2018). A regularly updated list of requirements is maintained at the ICOS webpage (http://www.icos-etc.eu/icos/ variables).

The specification of the spatial and temporal sampling design is a key aspect for the standardisation of the observations. Due to the specific variability of the variables of interest, the measurements need to be taken at distinct temporal frequencies and replications. They are characterised by different spatial coverage and the sampling design is designed in order to ensure representativeness for the target area. The target area of an ecosystem station is defined as a sufficiently homogeneous area for monitoring by the tower-based EC system (30 min averaged fluxes), that is required at each ICOS ecosystem station. The target area should include the majority of the footprint area contributing to the EC fluxes during most atmospheric conditions. The EC footprint differs between stations because of the ecosystem type and the associated measurement height, roughness length and prevailing atmospheric conditions. Continuous and sparse sampling plots for vegetation and soil characteristics are placed inside the target area (Saunders et al., 2018; and Gielen et al., 2018).

Whereas EC flux measurements of $\mathrm{CO}_{2}, \mathrm{H}_{2} \mathrm{O}$ and turbulent heat fluxes (Rebmann et al., 2018; Sabbatini et al., 2018) are mandatory at each ICOS Class 1 and Class 2 ecosystem station, $\mathrm{CH}_{4}$ and $\mathrm{N}_{2} \mathrm{O}$ EC flux measurements (Nemitz et al., 2018) only need to be included at sites where these gases are of importance, for example in wetlands $\left(\mathrm{CH}_{4}\right)$ and agricultural fields $\left(\mathrm{N}_{2} \mathrm{O}\right)$. Complementary to the EC measurements, automated soil chamber measurements (Pavelka et al., 2018) are also part of the portfolio. 
Chambers need to be installed within the EC footprint, capturing the temporal variability of ecosystem respiration with a minimum temporal resolution of one measurement per hour per gas and per chamber at least during the growing season. In order to investigate the spatial heterogeneity of GHG fluxes, additional manual soil chamber surveys are recommended and should cover seasonal changes and ecosystem specific events such as fertilisation/harvest.

As the EC method measures turbulent fluxes at a prescribed height above the vegetation surface, a concept for optimised measurements of the storage change in the air column underneath the EC system, considering horizontal heterogeneity, was developed for ICOS stations (for GHG storage flux measurements, Montagnani et al., 2018). Air temperature and gas concentration profiles for storage quantification are measured on the EC tower. In addition to the air column beneath the above-canopy sensors, heat storage fluxes are also measured in soils and water bodies.

Mandatory microclimate measurements are taken either in close vicinity to the sonic anemometer (ambient air temperature, barometric pressure and relative humidity) or at a sufficient distance from the tower to avoid shading and flow distortion (radiation, Carrara et al., 2018; precipitation, Dengel et al., 2018). A back-up meteorological station ensures the availability of meteorological variables controlling GHG exchange for quality assurance and gap-filling.

The portfolio of observations at ICOS ecosystem stations further includes distinct vegetation characteristics and dynamics, including foliar analyses (Loustau et al., 2018), green area index (GAI) or, alternatively in forest ecosystems, plant area index (PAI) and the yearly aboveground net primary production (ANPP; Gielen et al., 2018), as well as plant phenology (Hufkens et al., 2018). The temporal sampling design for repeated vegetation measurements primarily follows the course of phenological events. Management and disturbance events (e.g. harvest, wind throw, fire, pest infestation, and drought) are further constraints for the temporal sampling design of vegetation measurements. Phenological observations acquired consecutively at a daily timescale by automated digital cameras facilitate the link with climatic variables and measured fluxes (Wingate et al., 2015).

In addition, continuous soil temperature and moisture measurements are crucial variables at ICOS ecosystem stations (Op de Beeck et al., 2018). The behaviour of the soil as a GHG source or sink is determined on the basis of changes in SOC and soil N stocks (Arrouays et al., 2018), that are measured every five to ten years as their changes are detectable only over larger timescales (decades, Conen et al., 2003).

\section{Current status and outlook}

As of June 2018 the ICOS ecosystem station network is comprised of 77 stations in 12 countries observing seven terrestrial ecosystem types, i.e. cropland, forest, grassland, wetland, heath/ shrubland, SRF, an urban environment and one lake representing a freshwater ecosystem (Fig. 2, https://www.icos-cp.eu for updated information). The stations form a basic framework that is in the process of refinement through addition of further stations, that aim to represent European climatic conditions and land cover.

Figure 2a shows that current ICOS ecosystem stations are concentrated in Central-European countries and Southern Scandinavia, and missing in many Mediterranean and Southeast/East European countries. This lack of representativity in certain regions is related to, for instance, country-specific financial support for participation in ICOS. The climatic variability of the current station network in comparison to the whole European continent is shown in Fig. 2b. The three ICOS ecosystem stations in Greenland (two heathland and one wetland station) and similarly the three stations in French Guiana (two forest stations, one grassland station) are not included in this figure, as they do not belong geographically to the European continent. The station distribution indicates, that the network is best representing the upper to mid range annual air temperature (MAT) and precipitation (MAP) regimes (University of East Anglia Climatic Research Unit: CRU TS4.01), considering the European mean MAT and MAP of about $4.7^{\circ} \mathrm{C}$ and $648 \mathrm{~mm}$, respectively. The most apparent lack of representation concerns regions with $\mathrm{MAT}<-2^{\circ} \mathrm{C}$. Only a few stations, located in Northern Scandinavia, represent regions with MAT $<0^{\circ} \mathrm{C}$. Other regions of the European climate space poorly represented by the network are areas combining high MAP with MAT $<10^{\circ} \mathrm{C}$ in addition to those with the driest climatic conditions $(<500 \mathrm{~mm})$. The four main ecosystem types of the ICOS ecosystem network (forests, croplands, grasslands, wetlands) account for $93 \%$ of the stations (Fig. 2c). $46 \%$ of ICOS ecosystem stations on the European continent are located in forests, representing close to their actual proportional coverage of about $49 \%$ on the European continent (European Forest Institute, Päivinen et al., 2001; Schuck et al., 2001; Kempeneers et al., 2011; excluding south-eastern parts of the Volga region and the polar archipelagos Svalbard, Franz Josef Land and Novaya Zemlya). Forest ecosystem stations represent best the climatic variability covered by the network. The station classes are almost evenly distributed among the stations (Fig. 2c), however, large differences exist between the ecosystem types.

The inclusion of further stations, that can be either existing measurement stations joining ICOS or newly established stations, should ideally strategically address the gaps within the spatial distribution of the sites. However, country-specific funding and scientific priorities will determine how equally distributed across Europe the ecosystem (and further the atmospheric and oceanic) observations within ICOS will be. 


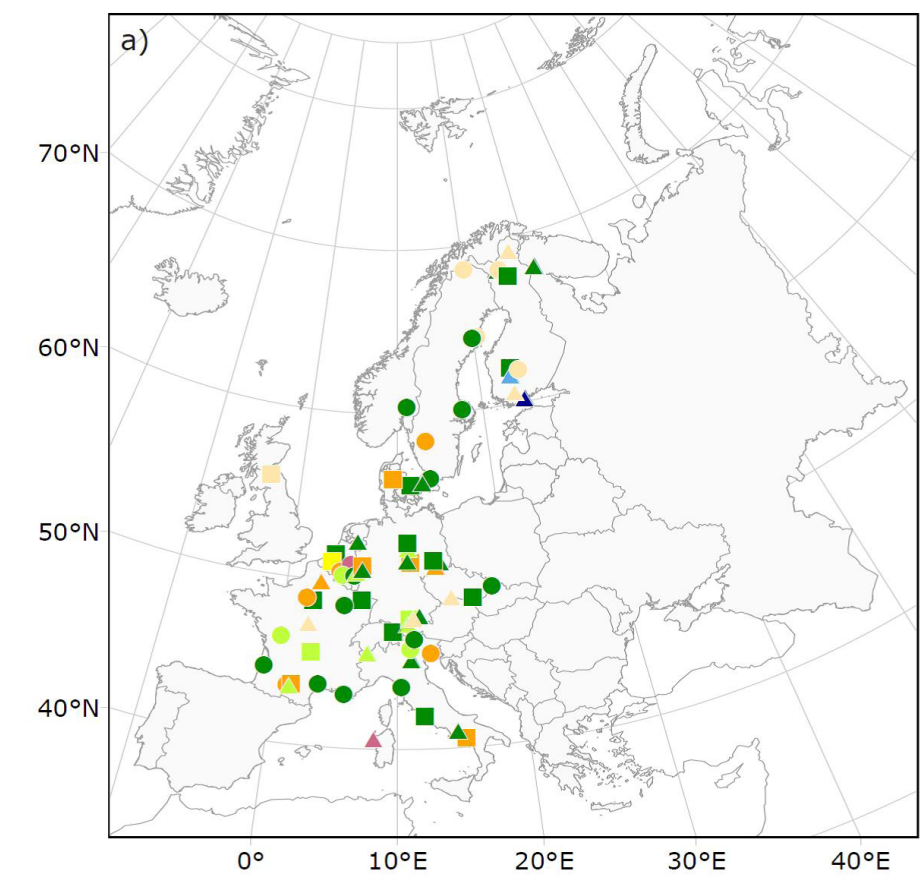

c) Proportional distribution of ecosystem types...
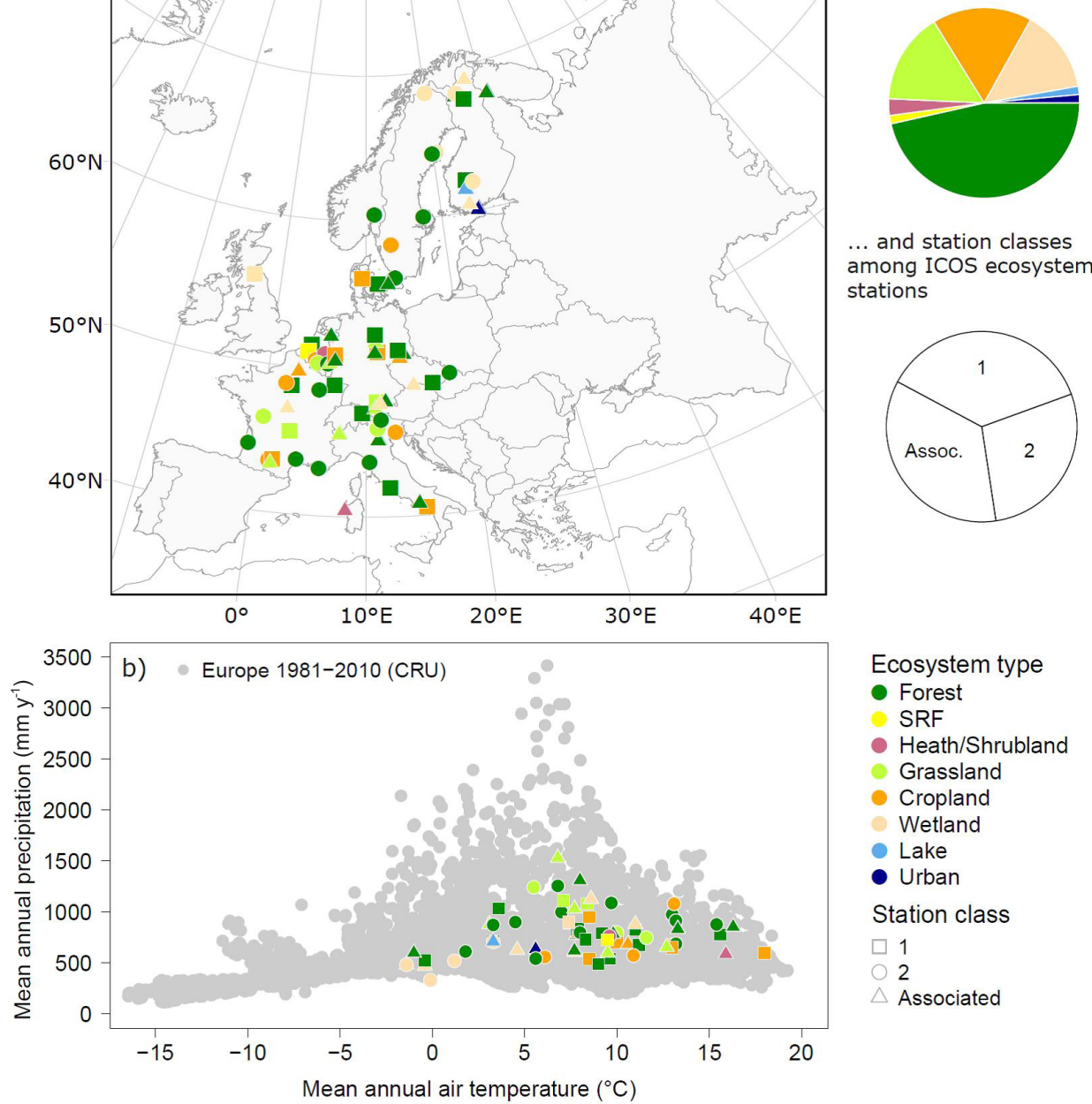

\section{Ecosystem type}

- Forest

SRF

- Heath/Shrubland

- Grassland

- Cropland

- Wetland

- Lake

- Urban

Station class

$\square 1$

- 2

$\triangle$ Associated

Fig. 2. Overview of ICOS ecosystem stations (Candidate stations and stations with approved label) as of January 2018. Colours indicate the ecosystem types $(\mathrm{SRF}=$ Short rotation forestry), and shapes the station classes (see lower panel legend). Stations in Greenland and French Guiana are not included here. a) Spatial distribution of stations on the European continent. Data sources: ArcGis, 2012 (European continent); NOAA, 2016 (Coastlines and European countries). b) Climatological distribution of stations with regard to MAT and MAP (note that averaging periods for both MAT and MAP vary for the different stations) in comparison to MAT and MAP for the reference period 1981-2010 on the European continent for $0.5^{\circ}$ grid cells (filled grey circles). Data sources: ArcGis, 2012 (European continent); University of East Anglia Climatic Research Unit (CRU TS4.01). c) Proportional distribution of ecosystem types and station classes among the stations.

The ICOS ecosystem protocols published in this International Agrophysics issue and the related specific instruction documents mark an important milestone in the developmental evolution of a network of stations to a coherent infrastructure where standardisation is a key feature. The ecosystem stations are currently implementing their compliance to the standards. For four of these stations (one in cropland, grassland, wetland and forest) the class labels are already approved, now transferring the network into the operational status. The ICOS RI as a whole is currently developing strategies to be highly standardised and innovative at the same time. This strategy has several components:
- Global scientific and technical cooperation with large RIs in other regions and within FLUXNET. Furthermore, a research dialogue working towards political decision making where societal demands are translated into scientific questions and connected observational technologies.

- Cooperation with industrial partners to develop better instrumentation and new methods. In this cooperation, the network of ICOS ecosystem stations and the related scientific and technical competence can be seen as a platform for innovation.

- Internal processes to further develop the ICOS standards. These processes have been defined by internal rules and procedures that ensure the participation of all involved parties. 
ICOS is currently among the globally leading environmental RIs focused on C and GHG observations. While ICOS observations span the atmosphere, terrestrial ecosystems and oceans with a focus on C and GHG dynamics, other observation networks may be restricted to terrestrial and freshwater ecosystems and bridge the gap to more ecologically focussed research and conservation communities (Bonan et al., 2012). In its cross-domain approach connecting ecosystem observations with similarly standardised observations in the atmosphere and ocean ICOS will serve as a prototype beyond Europe. It already includes several geographically adjacent key regions in Africa and Eurasia (atmospheric and oceanic domains). ICOS is also a regional contributor to the GCP investigating the global $\mathrm{C}$ cycle and other interacting biogeochemical cycles and is actively promoting and following the development of a global GHG observation system.

\section{CONCLUSIONS}

1. Climate change research requires integrated, standardised, high-precision and long-term observations of C, N, GHGs, water and energy that are reproducible and based on in-situ measurements.

2. The pan-European RI ICOS provides in-situ longterm ( $\geq 20$ years) observations of GHG $\left(\mathrm{CO}_{2}, \mathrm{CH}_{4}, \mathrm{~N}_{2} \mathrm{O}\right.$, $\mathrm{H}_{2} \mathrm{O}$ ) fluxes and concentrations in Europe and adjacent regions. A key characteristic of ICOS is the integration of the three domains atmosphere, terrestrial ecosystems and oceans.

3. The observations facilitate in-depth studies on the GHG balance, the $\mathrm{C}$ cycle, current and future climate feedbacks, and the evaluation of suitable climate change mitigation and adaptation strategies.

4. The ICOS ecosystem network provides GHG fluxes and ancillary measurements for terrestrial ecosystems, including microclimate, vegetation and soil characteristics, and helps to identify and understand the GHG exchange dynamics and their role in $\mathrm{C}$ cycling with regard to climate change.

5. Seven terrestrial and one freshwater ecosystem types are monitored in the ICOS ecosystem network: croplands, forests, grasslands, wetlands, heath/shrublands, SRF, urban environments and lakes. The grouping of ecosystem stations into three classes with different standardisation requirements allows for a high level of participation in the network and distinct data applications.

6 . The methodological framework for the ICOS ecosystem network is described in a coherent set of guidelines (see the papers of this issue), that were developed by the scientific community during an extensive discussion process. The guidelines justify which environmental variables are necessary in order to understand the $\mathrm{C}$ and GHG dynamics and how they need to be measured.
7. The high level of standardisation of the hardware, software and methods employed by ICOS increases the utility and reliability of the resulting data products. The degree of standardisation achieved in ICOS can be considered as the biggest innovation in the transition from networks to an integrated RI. In the ecosystem domain, standardisation is facilitating inter-annual and inter-site comparability, cross-site synthesis and straightforward data assimilation in models.

8. The success of ICOS depends on the use of its free and open-access multi-level data products by the user communities, thus the communication of stakeholders and end-users is crucial for ICOS in order to achieve its scientific potential and societal value.

\section{ACKNOWLEDGMENTS}

Many scientists and engineers have contributed to the development of ecosystem flux measurements during the past decades. The basic idea for the ICOS protocols was to integrate as many of them into working groups as possible to achieve a broad consensus and even impact beyond the Research Infrastructure itself. Not all of them are on the list of co-authors of this paper or of other papers in this special issue. Notwithstanding, the authors acknowledge their contribution to the process and particularly want to mention Ernst-Detlef Schulze, Han Dolman, Riccardo Valentini, Reinhart Ceulemans and Philippe Ciais for their early engagement in EU projects from the 1990s on and for bringing ICOS to the ESFRI roadmap in the early 2000s. Dario Papale, Ivan Janssens and Denis Loustau are thanked for their intense work in the ICOS Ecosystem Thematic Centre for standardisation of the network and their constructive contributions towards the definition of the protocols.

D.F. was financed by ICOS Finland and ICOS ERIC (Academy of Finland projects 281255 and 281250, respectively), and hosted by the University of Helsinki and Thünen Institute of Climate-Smart Agriculture. N.B, L.H., P.D'O. and L.M. acknowledge funds received under the Swiss National Science Foundation funded project ICOS-CH (grant agreement: 20FI21_148992) and of ETH Zurich (0-23184-15). The AmeriFlux Network is supported by the U.S. Department of Energy's Office of Science under Contract No. DE-AC02-05CH11231. The National Ecological Observatory Network is a project sponsored by the National Science Foundation and managed under cooperative agreement by Battelle Ecology, Inc. This material is based upon work supported by the National Science Foundation (grant DBI-0752017). Any opinions, findings, and conclusions or recommendations expressed in this material are those of the author and do not necessarily reflect the views of the National Science Foundation. M.A., M.P. and L.Š. were supported by the Ministry of Education, Youth and Sports of the Czech Republic within the CzeCOS program, grant number LM2015061, and 
within the National Sustainability Program I (NPU I), grant number LO1415. N.A. acknowledges the support of ICOSBelgium and Fonds-Wetenschappelijk Onderzoek (FWO).

Conflict of interest: The Authors declare no conflict of interest.

\section{REFERENCES}

Anthoni P.M., Knohl A., Rebmann C., Freibauer A., Mund M., Ziegler W., Kolle O., and Schulze E.-D., 2004. Forest and agricultural land-use-dependent $\mathrm{CO}_{2}$ exchange in Thuringia, Germany. Glob. Change Biol., 10, 2005-2019, doi:10.1111/j.1365-2486.2004.00863.x.

ArcGis, 2012. Continents shapefile, http://www.arcgis.com/ home/item.html?id=3c4741e22e2e4a f2bd4050511b9fc6ad (28 Dec 2017).

Arneth A., Harrison S.P., Zaehle S., et al., 2010. Terrestrial biogeochemical feedbacks in the climate system. Nat. Geosci., 3, 525-532, doi:10.1038/ngeo905.

Arrouays D., Saby N.P.A., Boukir H., et al., 2018. Soil sampling and preparation for monitoring soil carbon. Int. Agrophys., 32, 633-643.

Aubinet M., Grelle A., Ibrom A., et al., 2000. Estimates of the annual net carbon and water exchange of European forests: The EUROFLUX Methodology. Advances. Ecol. Res., 30, 113-175.

Aubinet M., Moureaux C., Bodson B., Dufranne D., Heinesch B., Suleau M., Vancutsem F., and Vilret A., 2009. Carbon sequestration by a crop during a four year rotational cycle. Agr. Forest Meteorol., 149, 407-418, doi:10.1016/j. agrformet.2008.09.003.

Aurela M., Laurila T., and Tuovinen J.-P., 2004. The timing of snow melt controls the annual $\mathrm{CO}_{2}$ balance in a subarctic fen. Geophys. Res. Lett, 31, L16119, doi:10.1029/2004G L020315.

Baldocchi D., 2003. Assessing the eddy covariance technique for evaluating carbon dioxide exchange rates of ecosystems: past, present and future. Glob. Change Biol., 9, 479-492, doi:10.1046/j.1365-2486.2003.00629.x.

Baldocchi D., 2014. Measuring fluxes of trace gases and energy between ecosystems and the atmosphere - the state and future of the eddy covariance method. Glob. Change Biol, 20, 3600-3609, doi: 10.1111/gcb.12649.

Baldocchi D., 2008. 'Breathing' of the terrestrial biosphere: Lessons learned from a global network of carbon dioxide flux measurement systems. Aust. J. Bot., 56, 1-26, doi:10.1071/BT07151.

Baldocchi D., Black T.A., Curtis P.S., et al., 2005. Predicting the onset of net carbon uptake by deciduous forests with soil temperature and climate data: a synthesis of FLUXNET data. Int. J. Biometeorol., 49, 377-387, doi:10.1641/ B580708.

Baldocchi D., Chu H., and Reichstein M., 2017. Inter-annual variability of net and gross ecosystem carbon fluxes: A review. Agr. Forest Meteorol., 249, 520-533, doi:10.1016/j. agrformet.2017.05.015.

Baldocchi D., Falge E., Gu L., et al., 2001. FLUXNET: A new tool to study the temporal and spatial variability of ecosystem-scale carbon dioxide, water vapor, and energy flux densities. B Am. Meteorol. Soc., 82(11), 2415-2434, doi: 10.1175/1520-0477(2001)08260;2415:fantts62;2.3.co;2.
Baldocchi D., Reichstein M., Papale, D., Koteen L., Vargas R., Agarwal D., and Cook R., 2012. The role of trace gas flux networks in the Biogeosciences. EOS, 93(23), 217-224, doi:10.1029/2012EO230001.

Ballantyne A.P., Alden C.B., Miller J.B., Tans P.P., and White J.W.C., 2012. Increase in observed net carbon dioxide uptake by land and oceans during the past 50 years. Nature, 488, 70-72, doi: 10.1038/nature11299.

Battin T.J., Luyssaert S., Kaplan L.A., Aufdenkampe A.K., Richter A., and Tranvik L.J., 2009. The boundless carbon cycle. Nat. Geosci., 2, 598-600, doi:10.1038/ngeo618.

Bellassen V. and Luyssaert S., 2014. Comment: Carbon sequestration: Managing forests in uncertain times. Nature, 506, 153-155, doi:10.1038/506153a.

Bloom A.A., Exbrayat J.-F., van der Velde I.R., Feng L., and Williams M., 2016. The decadal state of the terrestrial carbon cycle: Global retrievals of terrestrial carbon allocation, pools, and residence times. PNAS, 113(5), 1285-1290, doi/10.1073/pnas.1515160113.

Bonan G.B., Levis S., and Wieder W.R., 2012. A modeller's perspective of long-term integrated data series of ecosystematmosphere processes. iLEAPS Newsletter, 12, September 2012, 6-9.

Bousquet P., Peylin P., Ciais P., Le Quéré C., Friedlingstein P., and Tans P.P., 2000. Regional changes in carbon dioxide fluxes of land and oceans since 1980. Science, 290, 13421346, doi:10.1126/science.290.5495.1342.

Bréda N.J.J., 2003. Ground-based measurements of leaf area index: a review of methods, instruments and current controversies. J. Exp. Bot., 54, 2403-2417.

Canadell J.G., Pataki D.E., Gifford R., Houghton R.A., Luo Y., Raupach M.R., Smith P., and Steffen W., 2007. Saturation of the Terrestrial Carbon Sink. In: Terrestrial Ecosystems in a Changing World (Eds J.G. Canadell, D. Pataki, L. Pitelka). The IGBP Series, Springer Verlag, Berlin, Heidelberg, 59-78.

Carrara A., Kolari P., Op de Beeck M., et al., 2018. Radiation measurements at ICOS ecosystem stations. Int. Agrophys., 32, 589-605.

Ceschia E., Béziat P., Dejoux J. F., et al., 2010. Management effects on net ecosystem carbon and GHG budgets at European crop sites. Agr. Ecosys. Environ., 139, 363-383, doi:10.1016/j.agee.2010.09.020.

Christensen T.R., Jackowicz-Korczyński M., Aurela M., Crill P., Heliasz M., Masetpanov M., and Friborg T., 2012. Monitoring the multi-year carbon balance of a subarctic palsa mire with Micrometeorological techniques. AMBIO, 41, 207-217, doi:10.1007/s13280-012-0302-5.

Chu H., Baldocchi D., John R., Wolf S., and Reichstein M., 2017. Fluxes all of the time? A primer on the temporal representativeness of FLUXNET. J. Geophys. Res.-Biogeo., 122, 289-307, doi:10.1002/2016JG003576.

Ciais P., Dolman A.J., Bombelli A., et al., 2014. Current systematic carbon-cycle observations and the need for implementing a policy-relevant carbon observing system. Biogeosciences, 11, 3547-3602, doi:10.5194/bg-11-35472014.

Ciais P., Reichstein M., Viovy N., et al., 2005. Europe-wide reduction in primary productivity caused by the heat and drought in 2003. Nature, 437, 529-533, doi:10.1038/ nature 03972 . 
Ciais P., Tans P.P., Trolier M., White J.W., and Francey R.J., 1995. A large Northern Hemisphere terrestrial $\mathrm{CO}_{2}$ sink indicated by the $13 \mathrm{C} / 12 \mathrm{C}$ ratio of atmospheric $\mathrm{CO}_{2}$. Science, 269, 1098-1102, doi:10.1126/science.269.5227.1098.

Cole J.J., Caraco N.F., Kling G.W., and Kratz T.K., 1994. Carbon dioxide supersaturation in the surface waters of lakes. Science, 265, 1568-1570, doi:10.1126/science. 265.5178.1568.

Cole J.J., Prairie Y.T., Caraco N.F., et al., 2007. Plumbing the global carbon cycle: Integrating inland waters into the terrestrial carbon budget. Ecosystems, 10, 171-184, doi:10.1007/ s10021-006-9013-8.

Conen F., Yakutin M.V., and Sambuu A.D., 2003. Potential for detecting changes in soil organic carbon concentrations resulting from climate change. Glob. Change Biol., 9, 1515-1520, doi:10.1046/j.1529-8817.2003.00689.x.

Dai S.-Q., Li H., Xiong J., Ma J., Guo H.-Q., Xiao X., and Zhao B., 2018. Assessing the extent and impact of online data sharing in eddy covariance flux research. J. Geophys. Res-Biogeo., 123, 129-137, doi:10.1002/2017JG004277.

Danielewska A., Paoletti E., Clarke N., Olejnik J., Urbaniak M., Baran M., Siedlecki P., Hansen K., Lundin L., de Vries W., Nørgaard-Mikkelsen T., Dillen S., Fischer R., 2013. Towards the integration of research and monitoring at forest ecosystems in Europe. Forest Syst., 22, 535-545, doi:10.5424/fs/2013223-03675.

Dengel S., Graf A., Grünwald T., et al., 2018. Standardized precipitation measurements within ICOS: rain, snowfall and snow depth. Int. Agrophys., 32, 607-617.

Desjardins R.L. and Lemon E.R., 1974. Limitations of an eddycorrelation technique for the determination of the carbon dioxide and sensible heat fluxes. Boundary-Layer Meteorology, 5(4), 475-488.

Etzold S., Ruehr N.K., Zweifel R., Dobbertin M., Zingg A., Pluess P., Häsler R., Eugster W., and Buchmann N., 2011. The carbon balance of two contrasting mountain forest ecosystems in Switzerland: similar annual trends, but seasonal differences. Ecosystems, 14(8), 1289-1309, doi:10.1007/ s10021-011-9481-3.

Dušek J., Čížková H., Stellner S., Czerný R., and Květ J., 2012. Fluctuating water table affects gross ecosystem production and gross radiation use efficiency in a sedge-grass marsh. Hydrobiologia, 692(1), 57-66, doi:10.1007/s10750012-0998-z.

Eugster W., Moffat A., Ceschia E., et al., 2010. Management effects on European cropland respiration. Agric. Ecosys. Environ., 139, 346-362, doi:10.1016/j.agee.2010.09.001.

European Union, 2016. Urban Europe - Statistics on cities, towns and suburbs. EUROSTAT Statistical books, Luxembourg, European Union.

Falge E., Baldocchi D., Tenhunen J., et al., 2002. Seasonality of ecosystem respiration and gross primary production as derived from FLUXNET measurements. Agr. Forest Meteorol., 113, 53-74, doi:10.1016/S0168-1923(02)00102-8.

Fernández-Martínez M., Vicca S., Janssens I., et al., 2017. Atmospheric deposition, $\mathrm{CO}_{2}$, and change in the land carbon sink. Sci. Rep-UK, 7, 9632, doi:10.1038/s41598017-08755-8

Ferretti M. and Fischer R., 2013. Forest Monitoring: Methods for Terrestrial Investigations in Europe with an Overview of North America and Asia. Elsevier, Oxford.
Fisher J., Hayes D.J., Schwalm C.R., et al., 2018. Missing pieces to modeling the Arctic-Boreal puzzle. Environ. Res. Lett., 13, 020202, doi:10.1088/1748-9326/aa9d9a.

Fonselius S., 1958. Map and coordinates of the chemical and $\mathrm{CO}_{2}$ stations Western Europe. Tellus, 10(1), 170-171.

Frank D., Reichstein M., Bahn M., et al., 2015. Effects of climate extremes on the terrestrial carbon cycle: Concepts, processes and potential future impacts. Glob. Change Biol., 21, 2861-2880, doi: 10.1111/gcb.12916.

Gielen B., Acosta M., Altimir N., et al., 2018. Ancillary vegetation measurements at ICOS ecosystem stations. Int. Agrophys., 32, 645-664.

Gielen B., Op de Beeck M., Loustau D., Ceulemans R., Jordan A., and Papale D., 2017. Integrated Carbon Observation System (ICOS): An infrastructure to monitor the European greenhouse gas balance. In: Terrestrial ecosystem research infrastructures: Challenges and Opportunities (Eds Chabbi, H.W. Loescher). CRC Press, pp. 505-A. 520.

Gilmanov T.G., Aires L., Barcza Z., et al., 2010. Productivity, respiration, and light-response parameters of world grassland and agroecosystems derived from flux-tower measurements. Rangeland Ecol. Manag., 63, 16-39, doi:10.2111/REM-D-09-00072.1.

Gilmanov T.G., Soussana J.F., Aires L., et al., 2007. Partitioning European grassland net ecosystem $\mathrm{CO}_{2}$ exchange into gross primary productivity and ecosystem respiration using light response function analysis. Agric. Ecosys. Environ., 121, 93-120, doi:10.1016/j.agee.2006.12.008.

Goodwin P., Katavouta A., Roussenov V.M., Foster G.L., Rohling E.J., and Williams R.G., 2018. Pathways to 1.5 ${ }^{\circ} \mathrm{C}$ and $2{ }^{\circ} \mathrm{C}$ warming based on observational and geological constraints. Nat. Geosci., 11, 102-107, doi:10.1038/ s41561-017-0054-8.

Grünwald T. and Bernhofer C., 2007. A decade of carbon, water and energy flux measurements of an old spruce forest at the Anchor Station Tharandt. Tellus B, 59, 387-396, doi:10.1111/j.1600-0889.2007.00259.x.

Hari P., Andreae M. O., Kabat P., and Kulmala M., 2009. A comprehensive network of measuring stations to monitor climate change. Boreal Environ. Res., 14, 442-446.

Hari P., Petäjä T., Bäck J., et al., 2016. Conceptual design of a measurement network of the global change. Atmos. Chem. Phys., 16, 1017-1028, doi:10.5194/acp-16-10172016.

Helfter C., Campbell C., Dinsmore K.J., et al., 2015. Drivers of long-term variability in $\mathrm{CO}_{2}$ net ecosystem exchange in a temperate peatland. Biogeosciences, 12, 1799-1811, doi:10.5194/bg-12-1799-2015.

Heimann M. and Reichstein M., 2008. Terrestrial ecosystem carbon dynamics and climate feedbacks. Nature, 451, 289292, doi:10.1038/nature06591.

Holgerson M. and Raymond P.A., 2016. Large contribution to inland water $\mathrm{CO}_{2}$ and $\mathrm{CH}_{4}$ emissions from very small ponds. Nat. Geosci., 9, 222-226, doi:10.1038/ngeo2654.

Hollinger D.Y., Aber J., Dail B., et al., 2004. Spatial and temporal variability in forest-atmosphere $\mathrm{CO}_{2}$ exchange. Glob. Change Biol., 10, 1689-1706, doi:10.1111/j.1365-2486. 2004.00847.x. 
Houweling S., Bergamaschi P., Chevallier F., Heimann M., Kaminski T., Krol M., Michalak A.M., and Patra P., 2017. Global inverse modelling of $\mathrm{CH}_{4}$ sources and sinks: An overview of methods. Atmos. Chem. Phys., 17, 235256, doi:10.5194/acp-17-235-2017.

Hufkens K., Wingate L., Filippa G., et al., 2018. Assimilating phenology datasets automatically across ICOS ecosystem stations. Int. Agrophys., 32, 677-687.

Ilvesniemi H., Levula J., Ojansuu R., Kolari P., Kulmala L., Pumpanen J., Launiainen S., Vesala T., and Nikinmaa E., 2009. Long-term measurements of the carbon balance of a boreal Scots pine dominated forest ecosystem. Boreal Environ. Res., 14, 731-753.

IPCC, 2013. Climate Change 2013: The physical science basis, Contribution of Working Group I to the Fifth Assessment Report of the Intergovernmental Panel on Climate Change. (Eds Stocker T.F., Qin D., Plattner G.-K., Tignor M.M.B., Allen S.K., Boschung J., Nauels A., Xia Y., Bex V., and Midgley P.M.). Cambridge University Press, Cambridge, New York, doi:10.1017/CBO9781107415324.

Jackson R.B., Canadell J.G., Le Quéré C., Andrew R.M., Korsbakken J.I., Peters G.P., and Nakicenovic N., 2016. Reaching peak emissions, Nat. Clim. Change, 6, 7-10, doi:10.1038/nclimate2892.

Jung M., Le Maire G., Zaehle S., Luyssaert S., Vetter M., Churkina G., Ciais P., Viovy N., and Reichstein M., 2007. Assessing the ability of three land ecosystem models to simulate gross carbon uptake of forests from boreal to Mediterranean climate in Europe. Biogeosciences, 4, 647656, doi:10.5194/bg-4-647-2007.

Jung M., Reichstein M., and Bondeau A., 2009. Towards global empirical upscaling of FLUXNET eddy covariance observations: validation of a model tree ensemble approach using a biosphere model. Biogeosciences, 6, 2001-2013, doi: 10.5194/bg-6-2001-2009.

Jung M., Reichstein M., Margolis H. A., et al., 2011. Global patterns of land-atmosphere fluxes of carbon dioxide, latent heat, and sensible heat derived from eddy covariance, satellite, and meteorological observations. J. Geophys. Res., 116, G00J07, doi:10.1029/2010JG001566.

Kadygrov N., Broquet G., Chevallier F., Rivier L., Gerbig C., and Ciais P., 2015. On the potential of the ICOS atmospheric $\mathrm{CO}_{2}$ measurement network for estimating the biogenic $\mathrm{CO}_{2}$ budget of Europe. Atmos. Chem. Phys., 15, 12765-17787, doi:10.5194/acp-15-12765-2015.

Kaukolehto M. and Vesala T., 2014. From carbon-nitrogen research to standardization of greenhouse gas measurements, iLEAPS Newsletter, Special issue on Environmental Research Infrastructures, 20-22.

Keenan T.F., Hollinger D.Y., Bohrer G., Dragoni D., Munger J.W., Schmid H.P., and Richardson A.D., 2013. Increase in forest water-use efficiency as atmospheric carbon dioxide concentrations rise. Nature, 499(7458), 324-327, doi:10.1890/ 12-0747.1.

Kempeneers P., Sedano F., Seebach L., Strobl P., and SanMiguel-Ayanz J., 2011. Data fusion of different spatial resolution remote sensing images applied to forest type mapping, IEEE Trans. Geosci. Remote Sensing, 49(12), 4977-4986.

Kirschke S., Bousquet P., Ciais P., et al., 2013. Three decades of global methane sources and sinks. Nat. Geosci., 6, 813-823, doi:10.1038/NGEO1955.
Kondo M., Ichii K., Takagi H.. and Sasakawa M., 2015. Comparison of the data-driven top-down and bottom-up global terrestrial $\mathrm{CO}_{2}$ exchanges: GOSAT $\mathrm{CO}_{2}$ inversion and empirical eddy flux upscaling. J. Geophys. Res.Biogeosciences, 120, 1226-1245, doi:10.1002/ 2014 JG002866.

Kulmala M., 2018. Build a global Earth observatory. Nature, 553, 2-13, doi: 10.1038/d41586-017-08967-y.

Kumar J., Hoffman F.M., Hargrove W.W., and Collier N., 2016. Understanding the representativeness of FLUXNET for upscaling carbon flux from eddy covariance measurements. Earth Syst Sci Data Discuss, doi:10.5194/essd-2016-36.

Kutsch W., Aubinet M., Buchmann N., et al., 2010. The net biome production of full crop rotations in Europe. Agr. Ecosys. Environ., 139, 336-345.

Lafleur P.M., Roulet N.T., Bubier J.L., Frolking S., and Moore T.R., 2003. Interannual variability in the peatland-atmosphere carbon dioxide exchange at an ombrotrophic bog. Global Biogeochem. Cy., 17, 1036, doi:10.1029/ 2002 GB001983.

Law B.E., Falge E., Gu L., et al., 2002. Environmental controls over carbon dioxide and water vapor exchange of terrestrial vegetation. Agr. Forest Meteorol., 113, 97-120, doi:10.1016/ S0168-1923(02)00104-1.

Leip A., Skiba U., Vermeulen A., and Thompson R.L., 2018. A complete rethink is needed on how greenhouse gas emissions are quantified for national reporting. Atmos. Environ., 174, 237-240, doi:10.1016/j.atmosenv.2017.12.006

Le Quéré C., Andrew R.M., Canadell J.G., et al., 2016. Global Carbon Budget 2016. Earth Sys. Sci. Data, 8, 605-649, doi:10.5194/essd-8-605-2016.

Le Quéré C., Andrew R.M., Friedlingstein P., et al., 2018. Global Carbon Budget 2017. Earth Sys. Sci. Data, 10, 405448, doi:10.5194/essd-10-405-2018.

Levin I., 2012. Earth Science: The balance of the carbon budget. Nature, 488, 35-36, doi:10.1038/488035a.

Liu H.Z., Feng J.W., Järvi L., and Vesala T., 2012. Four-year (2006-2009) eddy covariance measurements of $\mathrm{CO}_{2}$ flux over an urban area in Beijing. Atmos. Chem. Phys., 12, 7881-7892, doi:10.5194/acp-12-7881-2012.

Loubet B., Laville P., Lehuger S., et al., 2011. Carbon, nitrogen and Greenhouse gases budgets over a four years crop rotation in northern France. Plant Soil, 343, 1/2, 109-137, doi:10.1007/s11104-011-0751-9.

Loustau D., Altimir N., Barbaste M., et al., 2018. Sampling and collecting foliage elements for the determination of foliar nutrients in ICOS ecosystem stations. Int. Agrophys., 32, 665-676.

Marcolla B., Cescatti A., Manca G., et al., 2011. Climatic controls and ecosystem responses drive the inter-annual variability of the net ecosystem exchange of an alpine meadow. Agr. Forest Meteorol., 151(9), 1223-1243, doi:10.1016/j.agrformet.2011.04.015.

Migliavacca M., Reichstein M., Richardson A.D., et al., 2011. Semiempirical modeling of abiotic and biotic factors controlling ecosystem respiration across eddy covariance sites. Glob. Change Biol., 17, 390-409, doi:10.1111/j.13652486.2010.02243.x.

Miglietta F. and Peressotti A., 1999. MEDEFLU - Summer drought reduces carbon fluxes in Mediterranean forest. Global Change NewsLetter, 39, 15-16. 
Millar R.J., Fuglestvedt J.S., Friedlingstein P., et al., 2017. Emission budgets and pathways consistent with limiting warming to $1.5^{\circ} \mathrm{C}$. Nat. Geosci., 10, 741-747, doi: $10.1038 /$ NGEO3031.

Montagnani L., Grünwald T., Kowalski A., et al., 2018. Estimating the storage term in eddy covariance measurements: the ICOS methodology. Int. Agrophys., 32, 551-567.

Nemitz E., Mammarella I., Ibrom A., et al., 2018. Standardisation of eddy-covariance flux measurements of methane and nitrous oxide. Int. Agrophys., 32, 517-549.

Niu S., Luo Y., Dietze M.C., Keenan T.F., Shi Z., Li J., and Chapin II F.S., 2014. The role of data assimilation in predictive ecology. Ecosphere, 5(5), 65, doi:10.1890/ ES13-00273.1.

NOAA, 2016. Global Self-consistent, Hierarchical, Highresolution Geography Database (GSHHG), Version 2.3.6 August 17, 2016, https://www.ngdc.noaa.gov/mgg/shorelines. The GSHHG Database is released under the GNU Lesser General Public license (http://www.gnu.org/licenses/lgpl.html).

Nosek B.A., Alter G., Banks G.C., et al., 2015. Promoting an open research culture. Science, 348(6242), 1422-1425, doi:10.1126/science.aab2374.

Op de Beeck M., Gielen B., Merbold L., et al., 2018. Soilmeteorological measurements at ICOS monitoring stations in terrestrial ecosystems. Int. Agrophys., 32, 619-631.

Osborne B., Saunders M., Walmsley D., Jones M., and Smith P., 2010. Key questions and uncertainties associated with the assessment of the cropland greenhouse gas balance. Agr. Ecosys. Environ., 139, 293-301, doi:10.1016/j.agee. 2010.05.009.

Pan Y., Birdsey R.A., Fang J., et al., 2011. A Large and Persistent Carbon Sink in the World's Forests. Science, 333, 6045, 988-993, doi: 10.1126/science.1201609.

Paoletti E., de Vries W., Mikkelsen T.N., Ibrom A., Larsen K.S., Tuovinen J.P., Serengil Y., Yurtseven I., Wieser G., and Matyssek R., 2014. Key Indicators of Air Pollution and Climate Change Impacts at Forest Supersites. In: Climate Change, Air Pollution and Global Challenges: Knowledge, Understanding and Perspectives from Forest Research (Eds Matyssek R., Clarke N., Cudlin P., Mikkelsen T.N., Tuovinen J.-P., Wieser G., Paoletti E.). Elsevier.

Papale D., Black T.A., Carvalhais N., et al., 2015. Effect of spatial sampling from European flux towers for estimating carbon and water fluxes with artificial neural networks. J. Geophys. Res-Biogeo., 120, 1941-1957, doi:10.1002/ 2015 JG002997.

Pavelka M., Acosta M., Kiese R., et al., 2018. Standardisation of chamber technique for $\mathrm{CO}_{2}, \mathrm{~N}_{2} \mathrm{O}$ and $\mathrm{CH}_{4}$ fluxes measurements from terrestrial ecosystems. Int. Agrophys., 32, 569-587.

Päivinen R., Lehikoinen M., Schuck A., Häme T., Väätäinen S., Kennedy P., and Folving S., 2001. Combining Earth Observation Data and Forest Statistics. EFI Research Report 14. European Forest Institute, Joint Research Centre - European Commission. EUR 19911 EN. 101p.

Peichl M., Öquist M., Ottosson-Löfvenius M., et al., 2014. A 12-year record reveals pre-growing season temperature and water table level threshold effects on the net carbon dioxide uptake in a boreal fen. Environ. Res. Lett., 9, 055006, doi:10.1088/1748-9326/9/5/055006.

Peters G.P., 2018. Beyond carbon budgets. Nat. Geosci., 11, 378383, doi:10.1038/s41561-018-0142-4.

Pilegaard K., Ibrom A., Courtney M.S., Hummelshøj P., and Jensen N.O., 2011. Increasing net $\mathrm{CO}_{2}$ uptake by a Danish beech forest during the period from 1996 to 2009. Agr. Forest Meteorol., 151, 934-946, doi:10.1016/j.agrformet. 2011.02.013.

Prescher A.-K., Grünwald T., and Bernhofer C., 2010. Land use regulates carbon budgets in eastern Germany: From NEE to NBP. Agr. Forest. Meteorol., 150, 1016-1025, doi:10.1016/j.agrformet.2010.03.008.

Rebmann C., Aubinet M., Schmid H.P., et al., 2018. ICOS eddy covariance flux-station site setup. Int. Agrophys., 32, 471-494.

Reichstein M., Bahn M., Ciais P., Frank D., Mahecha M.D., Seneviratne S.I., Zscheischler J., Beer C., Buchmann N., Frank D., Papale D., Rammig A., Smith P., Thonicke K., van der Velde M., Vicca S., Walz A., and Wattenbach M., 2013. Climate extremes and the carbon cycle. Nature, 500, 287-295, doi:10.1038/nature12350.

Richardson A.D., Black T.A., Ciais P., et al., 2010. Influence of spring and autumn phenological transitions on forest ecosystem productivity. Phil. Trans. R. Soc. B, 365, 3227-3246, doi:10.1098/rstb.2010.0102.

Rinne J., Riutta T., Pihlatie M., Aurela M., Haapanala S., Tuovinen J.-P., Tuittila E.-S., and Vesala T., 2007. Annual cycle of methane emission from a boreal fen measured by the eddy covariance technique. Tellus, 59B, 449-457, doi:10.1111/j.1600-0889.2007.00261.x.

Rogelj J., den Elzen M., Höhne N., et al., 2016. Paris Agreement climate proposals need a boost to keep warming well below $2{ }^{\circ} \mathrm{C}$. Nature, 534, 631-639, doi:10.1038/nature18307.

Sabbatini S., Mammarella I., Arriga N., et al., 2018. Eddy covariance raw data processing for $\mathrm{CO}_{2}$ and energy fluxes calculation at ICOS ecosystem stations. Int. Agrophys., 32, 495-515.

Saigusa N., Yamamoto S., Ohtsuka T., Murayama S., Kondo H., and Koizumi H., 2005. Inter-annual variability of carbon budget components in a cool-temperate deciduous forest in Japan (Takayama, AsiaFlux). Phyton-Annales Rei Botanicae, 45, 81-88.

Saunders M., Dengel S., Kolari P., et al., 2018. Assessing the impacts of site characteristics, management, disturbance and lateral fluxes on greenhouse gas dynamics. Int. Agrophys., 32, 457-469.

Schmid H.P., 2012. Future land-atmosphere observation platforms. iLEAPS newsletter, 12, September 2012, 4-5.

Schuck A., Van Brusselen J., Päivinen R., Häme T., Kennedy P., and Folving S., 2002. Compilation of a calibrated European forest map derived from NOAA-AVHRR data. European Forest Institute. EFI Internal Report 13, 44p. plus Annexes.

Schulze E.D., Ciais P., Luyssaert S., et al., 2010. The European carbon balance. Part 4: integration of carbon and other trace-gas fluxes. Glob. Change Biol., 16, 1451-1469, doi:10.1111/j.1365-2486.2010.02215.x. 
Schwalm C., Anderegg W.R.L., Michalak A.M., et al., 2017. Global patterns of drought recovery. Nature, 548, 202-205, doi: $10.1038 /$ nature 23021.

Schwalm C.R., Williams C.A., Schaefer K., et al., 2009. Assimilation exceeds respiration sensitivity to drought: A FLUXNET synthesis. Glob. Change Biol., 16, 657-670, doi:10.1111/j.1365-2486.2009.01991.x.

Seneviratne S.I., Rogelj J., Séférian R., et al., 2018. The many possible climates from the Paris Agreement's aim of $1.5^{\circ} \mathrm{C}$ warming. Nature, 558, 41-49, doi:10.1038/s41586-0180181-4.

Skiba U., Jones S.K., Drewer J., et al., 2009. Biosphere atmosphere exchange of reactive nitrogen and greenhouse gases at the NitroEurope core flux measurement sites: Measurement strategy and first annual data sets. Agr. Ecosys. Environ., 133, 139-149, doi:10.1016/j.agee.2009. 05.018 .

Smith P., Lanigan G., Kutsch W.L., et al., 2010. Measurements necessary for accessing the net ecosystem carbon budget of croplands. Agr. Ecosys. Environ., 139, 302-315, doi:10.1016/j.agee.2010.04.004.

Soegaard H., Nordstroem C., Friborg T., and Hansen B.U., 2000. Trace gas exchange in a high-arctic valley, 3. Integrating and scaling $\mathrm{CO}_{2}$ fluxes from canopy to landscape using flux data, footprint modelling, and remote sensing. Global Biogeochem. Cy., 14 (3), 725-744, doi:10.1029/1999 GB001137.

Soussana J.F., Allard V., Pilegaard K., et al., 2007. Full accounting of the greenhouse gas $\left(\mathrm{CO}_{2}, \mathrm{~N}_{2} \mathrm{O}, \mathrm{CH}_{4}\right)$ budget of nine European grassland sites. Agric. Ecosys. Environ., 121, 121-134, doi:10.1016/j.agee.2006.12.022.

Soussana J.F., Tallec T., and Blanfort V., 2010. Mitigating the greenhouse gas balance of ruminant production systems through carbon sequestration in grasslands. Animal, 4, 334350, doi:10.1017/S1751731109990784.

Tranvik L.J., Downing, J.A., Cotner J.B., et al., 2009. Lakes and reservoirs as regulators of carbon cycling and climate. Limnol. Oceanogr., 54(6), 2298-2314, doi: 10.4319/ 10.2009.54.6_part_2.2298.

UNECE ICP Forests Programme Co-ordinating Centre (Ed.), 2016. Manual on methods and criteria for harmonized sampling, assessment, monitoring and analysis of the effects of air pollution on forests. Thünen Institute of Forest Ecosystems, Eberswalde.

United Nations, 2014. Department of Economic and Social Affairs, Population Division: World Urbanization Prospects: The 2014 Revision, Highlights.

University of East Anglia Climatic Research Unit; Harris, I.C.; Jones, P.D., 2017. CRU TS4.01: Climatic Research Unit (CRU) Time-Series (TS) version 4.01 of high-resolution gridded data of month-by-month variation in climate (Jan. 1901- Dec. 2016). Centre for Environmental Data Analysis, 04 December 2017. doi:10.5285/58a8802721c94c66ae45c 3baa4d814d0.http://www.nationalarchives.gov.uk/doc/opengovernment-licence/version/3/.

Urbanski S., Barford C., Wofsy S., Kucharik C., Pyle E., Budney J., McKain K., Fitzjarrald D., Czikowsky M., and Munger J.W., 2007. Factors controlling $\mathrm{CO}_{2}$ exchange on timescales from hourly to decadal at Harvard Forest. J. Geophys. Res., 112, G02020, doi:10.1029/2006JG000293.
Valentini R., Matteucci G., Dolman A.J. et al., 2000. Respiration as the main determinant of carbon balance in European forests. Nature, 404, 861-865, doi:10.1038/35009084.

van Vuuren D.P., Edmonds J., Kainuma M., et al., 2011. The representative concentration pathways: an overview. Climate Change, 109, 5-31, doi:10.1007/s10584-0110148-z.

Velasco E. and Roth M., 2010. Cities as Net Sources of $\mathrm{CO}_{2}$ : Review of atmospheric $\mathrm{CO}_{2}$ exchange in urban environments measured by eddy covariance technique. Geogr. Compass, 4, 1238-1259, doi:10.1111/j.1749-8198.2010. 00384.x.

Villani M.G., Bergamaschi P., Krol M., Meirink J.F., and Dentener F., 2010. Inverse modeling of European $\mathrm{CH}_{4}$ emissions: sensitivity to the observational network. Atmos. Chem. Phys., 10, 1249-1267, doi:10.5194/acp-10-1249-2010.

Vitale L., Di Tommasi P., D’Urso G., and Magliulo V., 2016. The response of ecosystem carbon fluxes to LAI and environmental drivers in a maize crop grown in two contrasting seasons. Int. J. Biometeorol., 60(3), 411-420, doi:10.1007/ s00484-015-1038-2.

Wanninkhof R., Park G.-H., Takahashi T., et al., 2013. Global ocean carbon uptake: magnitude, variability and trends. Biogeosciences, 10, 1983-2000, doi:10.5194/bg-10-19832013.

Williams M., Richardson A.D., Reichstein M., et al., 2009. Improving land surface models with FLUXNET data. Biogeosciences, 6, 1341-1359, doi:10.5194/bg-6-13412009.

Wingate L., Ogée J., Cremonese E., et al., 2015. Interpreting canopy development and physiology using a European phenology camera network at flux sites. Biogeosciences, 12, 5995-6015, doi:10.5194/bg-12-5995-2015.

Wohlfahrt G., Hammerle A., Haslwanter A., et al., 2008. Seasonal and inter-annual variability of the net ecosystem $\mathrm{CO}_{2}$ exchange of a temperate mountain grassland: Effects of weather and management. J. Geophys. Res., 113, D08110, doi:10.1029/2007JD009286.

Wolf S., Keenan T.F., Fisher J.B., et al., 2016. Warm spring reduced carbon cycle impact oft he 2012 US summer drought. PNAS, 113(21), 5880-5885, doi:10.1073/ pnas. 1519620113 .

Wu J., Larsen K.S., van der Linden L., Beier C., Pilegaard K., and Ibrom A., 2013. Synthesis on the carbon budget and cycling in a Danish, temperate deciduous forest. Agr. Forest Meteorol., 181, 94-107, doi:10.1016/j.agrformet. 013.07.012.

Xiao J., Liu S., and Stoy P.C., 2016. Preface: Impacts of extreme climate events and disturbances on carbon dynamics. Biogeosciences, 13, 3665-3675, doi:10.5194/bg-13-36652016.

Zhu X.-J., Yu G.-R., He H.-L., et al., 2014. Geographical statistical assessment of carbon fluxes in terrestrial ecosystems of China: Results from upscaling network observations. Global Planet Change, 118, 52-61, doi:10.1016/j.gloplacha. 2014.04.003.

Zscheischler J., Mahecha M.D., Avitabile V., et al., 2017. Reviews and syntheses: An empirical spatiotemporal description of the global surface-atmosphere carbon fluxes: opportunities and data limitations. Biogeosciences, 14, 3685-3703, doi:10.5194/bg-14-3685-2017. 
Appendix

Table A1: Observation requirements and recommendations defined for ICOS Station Classes 1 and 2 for different ecosystem types $(1$ = mandatory for ICOS Station Class $1 ; 2$ = mandatory for ICOS Station Class 2 ; Fac $=$ facultative/ optional; N.R. = not required). The complete lists of variables for heath/ shrublands, SRF, urban environments and lakes are currently under discussion. For Associated Stations the standardisation is limited to a basic set of regular observations ${ }^{1}$.

\begin{tabular}{|c|c|c|c|c|c|c|}
\hline \multirow{2}{*}{$\begin{array}{l}\text { Variable } \\
\text { group }\end{array}$} & \multirow[b]{2}{*}{ Variable } & \multicolumn{4}{|c|}{ Ecosystem type } & \multirow[b]{2}{*}{ Acquisition frequency } \\
\hline & & Forest & $\begin{array}{c}\text { Grasslan } \\
\text { d }\end{array}$ & $\begin{array}{c}\text { Cropla } \\
\text { nd }\end{array}$ & $\begin{array}{c}\text { Wetlan } \\
\text { d }\end{array}$ & \\
\hline \multirow{9}{*}{$\begin{array}{c}\text { Fluxes, } \\
\text { storage \& } \\
\text { concentrations }\end{array}$} & $\mathrm{CO}_{2}, \mathrm{H}_{2} \mathrm{O}$ and sensible heat fluxes (EC) & $1 \& 2$ & $1 \& 2$ & $1 \& 2$ & $1 \& 2$ & $10-20 \mathrm{~Hz}$ \\
\hline & $\mathrm{CH}_{4}$ and $\mathrm{N}_{2} \mathrm{O}$ fluxes $(\mathrm{EC})$ & 1 & 1 & 1 & 1 & $10 \mathrm{~Hz}$ \\
\hline & Air $\mathrm{H}_{2} \mathrm{O}$ concentration & 1 & 1 & 1 & 1 & $1 \mathrm{~Hz}$ \\
\hline & $\mathrm{CO}_{2}$ profile & $1 \& 2$ & $1 \& 2$ & $1 \& 2$ & $1 \& 2$ & $1 \mathrm{~Hz}$ \\
\hline & Air temperature and humidity profile & $1 \& 2$ & $1 \& 2$ & $1 \& 2$ & $1 \& 2$ & $0.033-1 \mathrm{~Hz}$ \\
\hline & $\mathrm{CH}_{4}$ and $\mathrm{N}_{2} \mathrm{O}$ profiles & 1 & 1 & 1 & 1 & $1 \mathrm{~Hz}$ \\
\hline & Soil $\mathrm{CO}_{2}$ fluxes (automatic chambers) & 1 & 1 & 1 & 1 & $0.1-1 \mathrm{~Hz}$ \\
\hline & $\mathrm{CH}_{4}$ and $\mathrm{N}_{2} \mathrm{O}$ fluxes (automatic chambers) & 1 & 1 & 1 & 1 & $0.1-1 \mathrm{~Hz}$ \\
\hline & Manual chamber surveys & Fac & Fac & Fac & Fac & $\begin{array}{l}0.1-1 \mathrm{~Hz}\left(\mathrm{CO}_{2}\right), 15 \mathrm{~min} \\
\quad\left(\mathrm{CH}_{4}, \mathrm{~N}_{2} \mathrm{O}\right)\end{array}$ \\
\hline \multirow[t]{12}{*}{ Microclimate } & Air pressure & $1 \& 2$ & $1 \& 2$ & $1 \& 2$ & $1 \& 2$ & $\geq 0.033 \mathrm{~Hz}$ \\
\hline & $\begin{array}{l}\text { Wind speed and direction (additional to } \\
\text { 3D sonic) }\end{array}$ & 1 & 1 & 1 & 1 & $\geq 0.033 \mathrm{~Hz}$ \\
\hline & Total high accuracy precipitation & $1 \& 2$ & $1 \& 2$ & $1 \& 2$ & $1 \& 2$ & $\geq 0.017 \mathrm{~Hz}$ \\
\hline & Snow depth & $1 \& 2$ & $1 \& 2$ & $1 \& 2$ & $1 \& 2$ & $\geq 0.017 \mathrm{~Hz}$ \\
\hline & $\begin{array}{l}\text { Incoming, outgoing, net SW and } \mathrm{LW} \\
\text { radiation }\end{array}$ & $1 \& 2$ & $1 \& 2$ & $1 \& 2$ & $1 \& 2$ & $\geq 0.05 \mathrm{~Hz}$ \\
\hline & Incoming PPFD & $1 \& 2$ & $1 \& 2$ & $1 \& 2$ & $1 \& 2$ & $\geq 0.05 \mathrm{~Hz}$ \\
\hline & Outgoing PPFD & $1 \& 2$ & $1 \& 2$ & $1 \& 2$ & $1 \& 2$ & $\geq 0.05 \mathrm{~Hz}$ \\
\hline & Diffuse PPFD and/or SW radiation & 1 & 1 & 1 & 1 & $\geq 0.05 \mathrm{~Hz}$ \\
\hline & PPFD below canopy + ground reflected & Fac & Fac & Fac & N.R. & $\geq 0.05 \mathrm{~Hz}$ \\
\hline & Incoming SW radiation (high quality) & $\mathrm{Fac}$ & Fac & $\mathrm{Fac}$ & $\mathrm{Fac}$ & $\geq 0.05 \mathrm{~Hz}$ \\
\hline & Spectral reflectance & $\mathrm{Fac}$ & Fac & $\mathrm{Fac}$ & $\mathrm{Fac}$ & $\geq 0.05 \mathrm{~Hz}$ \\
\hline & $\begin{array}{l}\text { Backup meteorological station (TA, RH, } \\
\text { incoming SW, precipitation) }\end{array}$ & $1 \& 2$ & $1 \& 2$ & $1 \& 2$ & $1 \& 2$ & $\begin{array}{c}\geq 0.033 \mathrm{~Hz}(\mathrm{TA}, \mathrm{RH}), \geq \\
0.05 \mathrm{~Hz} \text { (SW), } \geq 0.017 \mathrm{~Hz} \\
\quad \text { (precip.) }\end{array}$ \\
\hline \multirow[t]{9}{*}{ Vegetation } & AGB & $1 \& 2$ & $1 \& 2$ & $1 \& 2$ & $1 \& 2$ & $\geq 2$ times/ year \\
\hline & GAI, PAI (forest) & $1 \& 2$ & $1 \& 2$ & $1 \& 2$ & $1 \& 2$ & $\geq 2$ times/ year \\
\hline & Litterfall & 1 & 1 & 1 & 1 & $\leq 2$ weeks (litter prod.) \\
\hline & LMA and Leaf nutrient content & $1 \& 2$ & $1 \& 2$ & $1 \& 2$ & $1 \& 2$ & $1-3$ times/ year \\
\hline & Phenology-Camera pictures & 1 & 1 & 1 & 1 & $>6-8$ images/ day \\
\hline & Tree diameter (continuous) & 1 & N.R. & N.R. & N.R. & NA \\
\hline & Trunk and branches temperature & Fac & N.R. & N.R. & N.R. & NA \\
\hline & $\begin{array}{l}\text { Management and disturbances } \\
\text { information }\end{array}$ & $1 \& 2$ & $1 \& 2$ & $1 \& 2$ & $1 \& 2$ & dep. on site conditions \\
\hline & $\mathrm{C}$ and $\mathrm{N}$ import/export by management & $1 \& 2$ & $1 \& 2$ & $1 \& 2$ & $1 \& 2$ & dep. on site conditions \\
\hline \multirow[t]{8}{*}{ Soil } & Soil temperature profile & $1 \& 2$ & $1 \& 2$ & $1 \& 2$ & $1 \& 2$ & $\geq 0.017 \mathrm{~Hz}$ \\
\hline & Soil heat flux density & $1 \& 2$ & $1 \& 2$ & $1 \& 2$ & $1 \& 2$ & $\geq 0.017 \mathrm{~Hz}$ \\
\hline & Water table depth & $1 \& 2$ & $1 \& 2$ & $1 \& 2$ & $1 \& 2$ & $\geq 0.017 \mathrm{~Hz}$ \\
\hline & Soil water content profile & $1 \& 2$ & $1 \& 2$ & $1 \& 2$ & $1 \& 2$ & $\geq 0.017 \mathrm{~Hz}$ \\
\hline & Soil C content & $1 \& 2$ & $1 \& 2$ & $1 \& 2$ & $1 \& 2$ & $\leq 10$ years \\
\hline & Soil N content & Fac & Fac & Fac & $\mathrm{Fac}$ & $\leq 10$ years \\
\hline & Soil water $\mathrm{N}$ content & Fac & Fac & Fac & Fac & NA \\
\hline & DOC concentration & $\mathrm{Fac}$ & $\mathrm{Fac}$ & Fac & Fac & NA \\
\hline \multirow[t]{2}{*}{ Water bodies } & $\mathrm{O}_{2}, \rho \mathrm{CO}_{2}$ and $\rho \mathrm{N}_{2} \mathrm{O}$ concentration profile & N.R. & N.R. & N.R. & Fac & NA \\
\hline & $\mathrm{O}_{2}$ and $\rho \mathrm{CO}_{2}$ surface concentration & N.R. & N.R. & N.R. & Fac & NA \\
\hline
\end{tabular}

${ }^{1}$ The requirements for Associated stations include: EC sensible heat flux, concentration and flux of $\mathrm{H}_{2} \mathrm{O}$ and one more GHG $\left(\mathrm{CO}_{2}, \mathrm{CH}_{4}\right.$ or $\left.\mathrm{N}_{2} \mathrm{O}\right)$, GHG storage flux (vertical profile; forest ecosystems only), incoming solar radiation (SW or PPFD), ambient air temperature, relative humidity, precipitation, horizontal wind speed and wind direction, Leaf Area Index (LAI; total one-sided area of leaf tissue per unit ground surface area; Bréda, 2003) or GAI measured at its annual maximum, AGB and average soil texture, information on management practices and disturbances. 
Table A2: Acronyms used in the paper.

\begin{tabular}{ll}
\hline \multicolumn{1}{c}{ Acronym } & \multicolumn{1}{c}{ Full name } \\
\hline AGB & Aboveground biomass \\
ANPP & Aboveground net primary production \\
C & Carbon \\
EBC & Energy balance closure \\
EC & Eddy covariance \\
ECV & Essential climate variable \\
ERIC & European Research Infrastructure Consortium \\
ESM & Earth system model \\
ETC & Ecosystem Thematic Centre \\
GAI & Green area index \\
GHG & Greenhouse gas \\
ICOS PP & ICOS Preparatory Phase \\
LAI & Leaf Area Index \\
LMA & Leaf mass to area \\
LW & Long-wave \\
MAP & Mean annual precipitation \\
MAT & Mean annual air temperature \\
MSA & Monitoring Station Assembly \\
N & Nitrogen \\
NEE & Net ecosystem exchange \\
PPFD & Photosynthetic photon flux density \\
PI & Principal investigator \\
RCP & Representative concentration pathways \\
RI & Research infrastructure \\
SOCS & Soil organic carbon stocks \\
SRF & Short rotation forestry \\
SW & Short-wave \\
\hline
\end{tabular}


Table A3: Acronyms of research programmes and infrastructures, projects, observation networks, etc., their runtimes and links for further information.

\begin{tabular}{|c|c|c|c|}
\hline Acronym & Full name & Runtimes & Links for further information \\
\hline ACTRIS & $\begin{array}{l}\text { Aerosols, Clouds and Trace gases } \\
\text { Research Infrastructure }\end{array}$ & $\begin{array}{l}\text { ongoing since } \\
2011\end{array}$ & http://actris2.nilu.no/ \\
\hline AEROCARB & $\begin{array}{l}\text { Airborne European regional } \\
\text { observation of the carbon balance }\end{array}$ & $2000-2003$ & $\begin{array}{l}\text { http://cordis.europa.eu/project/rcn/52175 } \\
\text { de.html }\end{array}$ \\
\hline AnaEE & $\begin{array}{l}\text { Analysis and experimentation on } \\
\text { Ecosystems }\end{array}$ & $\begin{array}{l}\text { ongoing since } \\
2011\end{array}$ & https://www.anaee.com \\
\hline ANIMATE & $\begin{array}{l}\text { Atlantic network of interdisciplinary } \\
\text { moorings and timeseries for Europe }\end{array}$ & $2001-2004$ & $\begin{array}{l}\text { http://cordis.europa.eu/project/rcn/60097 } \\
\text { _de.html }\end{array}$ \\
\hline AmeriFlux & (Flux tower network in the Americas) & $\begin{array}{l}\text { ongoing since } \\
1996\end{array}$ & http://ameriflux.lbl.gov \\
\hline Asiaflux & (Flux tower network in Asia) & $\begin{array}{l}\text { ongoing since } \\
1999\end{array}$ & http://www.asiaflux.net \\
\hline CarboAfrica & $\begin{array}{l}\text { Quantification, understanding and } \\
\text { prediction of carbon cycle, and other } \\
\text { GHG gases, in Sub-Saharan Africa }\end{array}$ & $\begin{array}{l}\text { ongoing since } \\
2006\end{array}$ & $\begin{array}{l}\text { http://cordis.europa.eu/project/rcn/81403 } \\
\text { _de.html }\end{array}$ \\
\hline CarboAge & $\begin{array}{l}\text { Age-related dynamics of carbon } \\
\text { exchange in European forests. } \\
\text { Integrating net ecosystem productivity } \\
\text { in space and time. }\end{array}$ & $2000-2003$ & $\begin{array}{l}\text { http://cordis.europa.eu/project/rcn/51253 } \\
\text { _en.html }\end{array}$ \\
\hline CarboChange & $\begin{array}{l}\text { Changes in carbon uptake and } \\
\text { emissions by oceans in a changing } \\
\text { climate }\end{array}$ & $2011-2015$ & https://carbochange.w.uib.no \\
\hline CarboEuroFlux & $\begin{array}{l}\text { An investigation on carbon and energy } \\
\text { exchanges of terrestrial ecosystems in } \\
\text { Europe }\end{array}$ & $2000-2003$ & $\begin{array}{l}\text { http://www.cordis.europa.eu/project/ren/ } \\
\text { 52172_en.html }\end{array}$ \\
\hline CarboEurope IP & $\begin{array}{l}\text { (Assessment of the European } \\
\text { Terrestrial Carbon Balance) }\end{array}$ & 2004-2008 & http://www.carboeurope.org \\
\hline $\begin{array}{l}\text { CarboEurope } \\
\text { Cluster }\end{array}$ & - & $2000-2004$ & $\begin{array}{l}\text { http://www.copernicus.eu/projects/carbo- } \\
\text { europe }\end{array}$ \\
\hline CarboMont & $\begin{array}{l}\text { Effects of land-use changes on sources, } \\
\text { sinks and fluxes of carbon in European } \\
\text { mountain areas }\end{array}$ & $2001-2004$ & https://www.uibk.ac.at/carbomont \\
\hline CarboOcean IP & $\begin{array}{l}\text { (Marine carbon sources and sinks } \\
\text { assessment) }\end{array}$ & 2005-2009 & http://www.carboocean.org \\
\hline CAVASSOO & $\begin{array}{l}\text { Carbon variability studies by ships of } \\
\text { opportunity }\end{array}$ & $2000-2003$ & $\begin{array}{l}\text { http://cordis.europa.eu/project/rcn/52983 } \\
\text { en.html }\end{array}$ \\
\hline CHIOTTO & $\begin{array}{l}\text { Continuous high-precision tall tower } \\
\text { Observations of greenhouse gases }\end{array}$ & 2003-2006 & http://www.chiotto.org/summary.html \\
\hline COCOS & $\begin{array}{l}\text { Coordination action carbon observation } \\
\text { system }\end{array}$ & $2008-2011$ & $\begin{array}{l}\text { http://cordis.europa.eu/project/rcn/90996 } \\
\text { en.html }\end{array}$ \\
\hline COPERNICUS & $\begin{array}{l}\text { European Earth Observation } \\
\text { Programme }\end{array}$ & $\begin{array}{l}\text { ongoing since } \\
1998\end{array}$ & http://www.copernicus.eu \\
\hline DEFROST & $\begin{array}{l}\text { Depicting Ecosystem-Climate } \\
\text { Feedbacks from Permafrost, } \\
\text { Snow and Ice }\end{array}$ & $2009-2013$ & $\begin{array}{l}\text { http://www.toppforskningsinitiativet.org/ } \\
\text { en/programmer-1/program- } \\
\text { 2/prosjekter/ncoe-defrost }\end{array}$ \\
\hline ÉCLAIRE & $\begin{array}{l}\text { Effect of climate change on air } \\
\text { pollution impacts and response } \\
\text { strategies for European ecosystems }\end{array}$ & 2011-1015 & http://www.eclaire-fp7.eu \\
\hline eLTER RI & $\begin{array}{l}\text { Integrated European Long-Term } \\
\text { Ecosystem \& Socio-Ecological } \\
\text { Research Infrastructure }\end{array}$ & $\begin{array}{l}\text { ongoing since } \\
2002\end{array}$ & http://www.lter-europe.net/elter-esfri \\
\hline EMSO & $\begin{array}{l}\text { European Multidisciplinary Seafloor } \\
\text { and water-column Observatory }\end{array}$ & $\begin{array}{l}\text { ERIC since } \\
2016\end{array}$ & http://www.emso-eu.org \\
\hline
\end{tabular}


ENVRI

ESCOBA

ESFRI

EuroArgo

Euroflux

EU-

NOFRETETE

FORCAST

Fluxnet-Canada

FLUXNET

(GCCT)

GCOS

GCP

GEO

GEO-C

GEOSS

GHG Europe

IAGOS

IBP

ICOS

ICOS-INWIRE

ICP Forests

$\mathrm{IG}^{3} \mathrm{IS}$

IMECC

InGOS

IOCCP

Lifewatch
European Environmental Research Infrastructure

European Study of Carbon in the Ocean, Biosphere and Atmosphere European Strategic Forum for Research Infrastructures

European contribution to the Argo programme

(Long-term carbon dioxide and water vapour Fluxes of European forests and interactions with the climate system)

Nitrogen Oxides Emissions from

European Forest Ecosystems

Forest Carbon - Nitrogen Trajectories

(Canadian flux tower network)

(Network of regional EC tower networks)

The global terrestrial carbon cycle and its perturbation by man and climate Global Climate Observation System

Global Carbon Project

Group on Earth Observation

GEO Carbon and GHG Initiative

Global Earth Observation System of Systems

Greenhouse gas management in

European land use systems In-service Aircraft for a Global Observing System

International Biological Program

Integrated Carbon Observation System

ICOS - Improved sensors, network and interoperability for GMES

International Co-operative Programme on Assessment and Monitoring of Air Pollution Effects on Forests

Integrated Global Greenhouse Gases Information System

Infrastructure for measurements of the European carbon cycle

Integrated non- $\mathrm{CO}_{2}$ greenhouse gas

observing system

International Ocean Carbon

Coordination Project

E-Science European Infrastructure for
ENVRI

project 2011-

2014, ENVRI

community

ongoing

1996-1999

Ongoing since

2002

ongoing since

2008

1995-1998

2001-2004

2000-2003

1993-2014 and currently integrated in

AmeriFlux

ongoing since

1997

1993-1995

ongoing since

1992

Ongoing since

2001

Ongoing since

2005

Ongoing since

2017

ongoing since

2005

2010-2013

ongoing since

2005

1964-1974

ongoing since

2008, ERIC

since 2016

2013-2015

ongoing since 1985

ongoing since

2015

2007-2011

2011-2015

ongoing since

2005

ERIC since http://envri.eu/

http://cordis.europa.eu/project/rcn/30856 de.html

$\overline{\mathrm{h}} \mathrm{ttps}$ ://ec.europa.eu/research/infrastructu res/index_en.cfm?pg=esfri

http://www.euro-argo.eu

http://cordis.europa.eu/project/ren/30818 _en.html

http://cordis.europa.eu/project/ren/58308 en.html

$\overline{\mathrm{h} t t p}: / /$ cordis.europa.eu/project/rcn/51619 de.html

https://daac.ornl.gov/FLUXNET/guides/ FLUXNET_Canada.html,

http://fluxnet.fluxdata.org;

http://cordis.europa.eu/project/ren/5213 de.html

https://public.wmo.int/en/programmes/gl obal-climate-observing-system

http://www.globalcarbonproject.org

https://www.earthobservations.org

https://www.earthobservations.org/activit y.php?id=113

https://www.earthobservations.org/geoss. php

http://www.ghg-europe.eu

https://www.iagos.org

http://www.nasonline.org/aboutnas/history/archives/collections/ibp1964-1974-1.html

https://www.icos-ri.eu

http://www.icosinwire.lsce.ipsl.fr/welcome.html; http://icp-forests.net

http://www.wmo.int/pages/prog/arep/ga w/ghg/IG3IS-info.html http://imecc.ipsl.jussieu.fr/Data2.html

http://www.ingos-infrastructure.eu

http://www.ioccp.org

http://www.lifewatch.eu 


\begin{tabular}{|c|c|c|c|}
\hline \multirow[b]{2}{*}{ LTER } & Biodiversity and Ecosystem Research & 2017 & \\
\hline & Long Term Ecological Research & $\begin{array}{l}\text { LTER (US) } \\
\text { since 1980, } \\
\text { LTER-Europe } \\
\text { launched in } \\
2003\end{array}$ & $\begin{array}{l}\text { https://www.ilter.network; } \\
\text { http://www.lter-europe.net }\end{array}$ \\
\hline Medeflu & $\begin{array}{l}\text { (Flux measurement network in the } \\
\text { Mediterranean region) }\end{array}$ & $1997-1999$ & Miglietta and Peressotti (1999) \\
\hline NEON & $\begin{array}{l}\text { National Ecological Observatory } \\
\text { Network }\end{array}$ & $\begin{array}{l}\text { fully } \\
\text { operational } \\
\text { from } 2018 \\
\text { onwards }\end{array}$ & http://www.neonscience.org; \\
\hline NitroEurope IP & $\begin{array}{l}\text { (Integrated European research into the } \\
\text { nitrogen cycle) }\end{array}$ & $2006-2011$ & http://www.nitroeurope.eu; \\
\hline OzFlux & $\begin{array}{l}\text { (Australian and New Zealand flux } \\
\text { tower network) }\end{array}$ & $\begin{array}{l}\text { ongoing since } \\
2001\end{array}$ & http://www.ozflux.org.au/index.html \\
\hline RINGO & $\begin{array}{l}\text { Readiness of ICOS for Necessities of } \\
\text { Integrated Global Observations }\end{array}$ & 2017-2020 & https://www.icos-ri.eu/ringo \\
\hline SBSTA & $\begin{array}{l}\text { Subsidiary Body for Scientific and } \\
\text { Technical Advice }\end{array}$ & - & http://unfccc.int/bodies/body/6399.php \\
\hline TACOS & $\begin{array}{l}\text { Terrestrial and Atmospheric Carbon } \\
\text { Observing System infrastructure }\end{array}$ & 2001-2005 & $\begin{array}{l}\text { http://cordis.europa.eu/project/rcn/58165 } \\
\text { _en.html }\end{array}$ \\
\hline TENATSO & $\begin{array}{l}\text { Tropical Eastern North Atlantic Time- } \\
\text { Series Observatory }\end{array}$ & 2006-2008 & $\begin{array}{l}\overline{\mathrm{h}} \mathrm{ttp}: / / \text { outreach.eurosites.info/outreach/D } \\
\text { eepOceans/station.php?id=4 }\end{array}$ \\
\hline UNECE & $\begin{array}{l}\text { United Nations Economic Commission } \\
\text { for Europe }\end{array}$ & $\begin{array}{l}\text { ongoing since } \\
1947\end{array}$ & $\begin{array}{l}\text { https://www.unece.org/info/ece- } \\
\text { homepage.html }\end{array}$ \\
\hline UNFCCC & $\begin{array}{l}\text { United Nations Framework Convention } \\
\text { on Climate Change }\end{array}$ & $\begin{array}{l}\text { adopted in } \\
1992\end{array}$ & http://unfccc.int/2860.php \\
\hline VERIFY & $\begin{array}{l}\text { Observation-based system for } \\
\text { monitoring and verification of } \\
\text { greenhouse gases }\end{array}$ & $2018-2022$ & https://sc5.easme-web.eu/?p=776810 \\
\hline WMO & World Meteorological Organisation & $\begin{array}{l}\text { ongoing since } \\
1950\end{array}$ & https://public.wmo.int \\
\hline
\end{tabular}

